\title{
7DHC-induced changes of Kv1.3 operation contributes to modified $T$ cell function in Smith-Lemli-Opitz syndrome
}

\author{
András Balajthy ${ }^{1} \cdot$ Sándor Somodi $^{2} \cdot$ Zoltán Pethö $^{1} \cdot$ Mária Péter $^{3} \cdot$ Zoltán Varga $^{4} \cdot$ \\ Gabriella P. Szabó ${ }^{5}$ - György Paragh ${ }^{2}$ - László Vígh ${ }^{3}$ - György Panyi ${ }^{1}$ - Péter Hajdu ${ }^{6}$
}

Received: 15 May 2016 / Revised: 8 June 2016 / Accepted: 10 June 2016 /Published online: 17 June 2016

(C) Springer-Verlag Berlin Heidelberg 2016

\begin{abstract}
In vitro manipulation of membrane sterol level affects the regulation of ion channels and consequently certain cellular functions; however, a comprehensive study that confirms the pathophysiological significance of these results is missing. The malfunction of 7-dehydrocholesterol (7DHC) reductase in Smith-Lemli-Opitz syndrome (SLOS) leads to the elevation of the 7-dehydrocholesterol level in the plasma membrane. T lymphocytes were isolated from SLOS patients to assess the effect of the in vivo altered membrane sterol composition on the operation of the voltage-gated Kv1.3 channel and the ion channel-dependent mitogenic responses. We found that the kinetic and equilibrium parameters of Kv1.3 activation changed in SLOS cells. Identical changes in Kv1.3 operation were observed when control/healthy $\mathrm{T}$ cells were loaded with 7DHC. Removal of the putative sterol binding sites on Kv1.3 resulted in a phenotype that was not
\end{abstract}

Péter Hajdu

hajdup@med.unideb.hu

1 Department of Biophysics and Cell Biology, Faculty of General Medicine, University of Debrecen, Egyetem tér 1., Debrecen 4032, Hungary

2 Department of Internal Medicine, University of Debrecen, Egyetem tér 1., Debrecen 4032, Hungary

3 Institute of Biochemistry, Biological Research Center of the Hungarian Academy of Sciences, H-6726 SzegedTemesvári Krt. 62., Hungary

4 MTA-DE-NAP B Ion Channel Structure-Function Research Group, RCMM, University of Debrecen, DebrecenEgyetem tér 1., H-4032, Hungary

5 Department of Pediatrics, University of Debrecen, Egyetem tér 1., Debrecen 4032, Hungary

6 Department of Biophysics and Cell Biology, Faculty of Dentistry, University of Debrecen, Egyetem tér 1., Debrecen 4032, Hungary influenced by the elevation in membrane sterol level. Functional assays exhibited impaired activation and proliferation rate of $\mathrm{T}$ cells probably partially due to the modified Kv1.3 operation. We concluded that the altered membrane sterol composition hindered the operation of Kv1.3 as well as the ion channel-controlled $\mathrm{T}$ cell functions.

Keywords Smith-Lemli-Opitz syndrome Cholesterol . 7-Dehydrocholesterol · Voltage-gated ion channel $\cdot$ Kv1.3

\section{Introduction}

Cholesterol (CHOL) is a crucial component of the mammalian plasma membrane, it determines the biophysical properties of the lipid bilayer as well as the function of the embedded proteins. CHOL homeostasis of the mammalian cells is strictly regulated by complex mechanisms [51]. In the last decades, numerous malformation syndromes have been associated with the inborn error of the CHOL synthesis (reviewed in [46]). The link between reduced CHOL synthesis and a serious health condition was described first for the Smith-LemliOpitz syndrome (SLOS) $[29,59,65]$. The SLOS phenotypic spectrum is very broad, ranging from a mild disorder with behavioral and learning problems to a lethal malformation syndrome (incidence of SLOS is 1 in 39,000 births [17]) $[45,46]$. The disease is characterized by the constellation of severe birth defects affecting multiple organ systems (central nervous system, cardiac, pulmonoray, gastrointestinal). Craniofacial features (microcephaly, a small upturned nose, ptosis, and micrognathia) and the syndactily of the second and third toes are the most frequent physical manifestations of SLOS. Growth failure and feeding problems are also common in SLOS. Moreover, many SLOS infants have behaviour problems (autism, hyperactivity, self-injures behavior) [45, 
46]. Irons and his colleagues showed that the SLOS is caused by the deficiency of 7-dehyrocholesterol-reductase (DHCR7), which catalyzes the last step in the CHOL biosynthetic pathway [29]. Altered DHCR7 activity led to increased 7DHC and reduced CHOL levels both in the serum and in the plasma membrane of fibroblasts and erythrocytes $[16,61]$.The severity of the disease and life expectancy of the patients is mostly determined by initial serum CHOL level, while the ratio of 7DHC/CHOL has an additional prognostic value [5]. Oral cholesterol and simvastatin administration are used in the treatment of SLOS; however, retrospective studies did not confirm its effectiveness [12, 19, 24, 58].

Ion channels are pore-forming, integral membrane proteins allowing the transport of inorganic ions down their electrochemical gradient across the cell membrane. Voltage-gated potassium channels ( $\mathrm{Kv}$ channels) are the largest and most diverse group of the ion channels including up to 40 members [23]. They are composed of four, generally identical $\alpha$-subunits, each of which is composed of six transmembrane domains (S1-S6) connected by extracellular and intracellular loops. S5 and S6 segments with the pore loop between them form the pore domain (PD) of the channel which includes the ion conducting pore, whereas $\mathrm{S} 1-\mathrm{S} 4$ and the positively charged amino acids in S4 make up the voltage-sensing domain (VSD). Kv1.3, which belongs to the Shaker subfamily of $\mathrm{Kv}$ channels, is the predominant voltage-gated $\mathrm{K}^{+}$channel of human $\mathrm{T}$ lymphocytes $[18,39]$. The main function of $\mathrm{Kv} 1.3$ channels during $\mathrm{T}$ cell activation is the maintenance of a permissive membrane potential (approximately equal to $-50 \mathrm{mV}$ ) required for appropriate extracellular $\mathrm{Ca}^{2+}$ entry and proper $\mathrm{Ca}^{2+}$ signaling. By the use of Kv1.3-selective antagonists, lymphocyte proliferation and IL-2 production can be inhibited $[14,47]$. It has been reported earlier by several labs that CHOL is a significant regulator of various types of ion channels including Kv1.3 [27, 49, 52]. Generally, the excess CHOL content of the plasma membrane suppresses the ion channel activity by reducing the open probability or conductivity. These suppressing effects were shown not only for $\mathrm{Kv}$ channels but for $\mathrm{Ca}^{2+}$ and $\mathrm{Na}^{+}$channels as well [33]. On the other hand, some of the channels (e.g., TRPV channels and $\mathrm{ENaC}$ [33]) have been referred to as CHOL-dependent, whereby $\mathrm{CHOL}$ depletion reduces the activity of the channels. We showed earlier that the CHOL loading of T cell membrane significantly slowed the activation and inactivation kinetics of Kv1.3 and modified the parameters of the steady-state activation [27].

It was demonstrated that 7DHC can incorporate into biomembranes and SLOS patients have an increased 7DHC level in the plasma membrane [61]. Moreover, accumulation of the 7DHC in the plasma membrane can affect the physicalchemical behavior of the lipid bilayer, and also influence the function of membrane proteins by disrupting/modifying the raft structure and/or interacting directly with the proteins themselves $[11,30,61]$. The single-channel conductance of the $\mathrm{BK}_{\mathrm{Ca}}$ channel, which colocalizes with caveolin in $\mathrm{CHOL}-$ rich membrane domains, is reduced and the voltage dependence of the open probability is right-shifted in SLOS fibroblasts [48]. The function of $\mathrm{Na}^{+} / \mathrm{K}^{+}$ATPase is also decreased in SLOS fibroblast [48].

To our knowledge, there are no other reports, in which the altered biophysical parameters of a $\mathrm{Kv}$ channel and its functional consequences are demonstrated in cells isolated from SLOS subjects. Here, we demonstrate that the operation of Kv1.3 channels, which are also expressed in neuronal cells, is modified in T cells of SLOS patients as compared to healthy age-matched control. We have found that changes in the gating of Kv1.3 channels in SLOS lymphocytes were similar to those recorded in control $\mathrm{T}$ cells loaded with 7DHC using methyl- $\beta$-cyclodextrin/7DHC complex. Removal of the Cterminal end of Kv1.3 abolished the sterol sensitivity of Kv1.3, which proves interaction between the channel and membrane sterols. Furthermore, the modified operation of $\mathrm{Kv1} .3$ in the SLOS T cells was associated with impaired proliferation rate and a defect in the early steps of Kv1.3- and $\mathrm{Ca}^{2+}$-dependent activation pathway in $\mathrm{CD}^{+} \mathrm{T}$ cells. We propose that the ion channel-sterol interaction described in our study reveals a molecular mechanism that may contribute to various pathophysiological conditions via influencing the physiological function of ion channels.

\section{Material and methods}

\section{Patients}

All eight SLOS patients who were accessible in Hungary (age $7.65 \pm 2.23$ years) and eight age-matched control patients from Hungary (age $7.66 \pm 1.83$ years) were enrolled in the study. On the basis of clinical severity score, patients were assigned to three groups: score below 20 means mild disease, while typical SLOS patients have a score between 20 and 50, and above 50 the severe type of SLOS is manifested [5,41]. Three of the patients were characterized with mild disease (age 9 \pm 1.88 years, serum $7 \mathrm{DHC} 0.38 \pm 0.08 \mathrm{mmol} / \mathrm{l}$, serum $\mathrm{CHOL}$ was $2.64 \pm 0.36 \mathrm{mmol} / \mathrm{l}$ ), and five children with typical disease (age $7.4 \pm 2.13$ years, mean serum7DHC and CHOL level was $0.5 \pm 0.09$ and $1.44 \pm 0.26 \mathrm{mmol} / \mathrm{l}$, respectively). After setting up the diagnosis, all of the enrolled patients received dietary CHOL substitution [56]. Statin therapy was also started after diagnosis but in case of two patients it was suspended because of elevated liver enzymes. Informed consent was obtained from all individual participants included in the study. Human blood was obtained following a protocol approved by the Institutional Review Board of University of Debrecen. All procedures performed in studies involving human participants were in accordance with the ethical standards of the 
institutional research committee and with the 1964 Helsinki declaration and its later amendments or comparable ethical standards.

\section{Cells}

Five milliliters of heparinized human peripheral venous blood was drawn from SLOS patients and healthy control children. Mononuclear cells were separated by Ficoll-Hypaque density gradient centrifugation. Freshly isolated cells were used for CFSE assay, and the remaining mononuclear cells were frozen and stored at $-80^{\circ} \mathrm{C}$ until patch clamp and CD154 expression experiments. Following CFSE staining (see below) and activation, cells were cultured in 24- or 96-well plates at a cell density of $10^{6}$ cells $/ \mathrm{ml}$ in standard RMPI-1640 medium (Sigma-Aldrich Co., Saint Louis, MO, USA) containing $15 \mathrm{mM}$ HEPES buffer (Sigma-Aldrich Co., Hungary) at $37{ }^{\circ} \mathrm{C}$ in humid atmosphere with $5 \% \mathrm{CO}_{2}$. $\mathrm{CHO}$ cells (ATCC, Germany) were cultured in DMEM medium (Sigma-Aldrich, Hungary), which also contained $10 \%$ FBS, L-glutamine $(2 \mathrm{mM})$, penicillin $(100 \mathrm{U} / \mathrm{l})$, and streptomycin $(100 \mathrm{mg} / \mathrm{l})$. Cells were maintained at $37{ }^{\circ} \mathrm{C}$ in a humidified atmosphere of $5 \%$ of $\mathrm{CO}_{2}$ and $95 \%$ air. Cells were passed every 2-3 days. CHO cells were transduced with retroviral particles containing mGFP-Kv1.3-WT and mGFP-Kv1.3 $\Delta \mathrm{C}$ constructs as described in [57].

\section{Analysis of the sterol composition of red blood cells using GC-MS}

Gas chromatography-mass spectrometry (GC-MS) experiments were carried out by use of the standard protocols. Before extraction ergosterol, as internal standard for sterol quantitation was added to the homogenates $(10 \mu \mathrm{g} /$ protein $\mathrm{mg})$. Lipids were extracted according to a modified Folch procedure as described in [4]. Protein content of cell homogenates was determined with the BCA protein assay kit (Thermo Scientific) using the protocol recommended by the manufacturer. Quantitative analysis of CHOL and 7DHC was carried out by a GC-MS system (GCMS-QP2010, Shimadzu) equipped with a BPX-1 capillary column $(10 \mathrm{~m} \times 0.1 \mathrm{~mm} \times 0.1 \mu \mathrm{m}$ film thickness $)$. An aliquot of the extracts (corresponding to $50 \mu \mathrm{g}$ protein) was evaporated, the residue redissolved in $25 \mu$ l benzene followed by addition of $3 \mu \mathrm{l}$, O-bis(trimethylsilyl)acetamide and kept at room temperature for an hour. A 1- $\mu$ l aliquot of the resulting trimethylsilyl ether derivative of the different sterols was injected onto the column programmed at $30{ }^{\circ} \mathrm{C} / \mathrm{min}$ from 150 to $290{ }^{\circ} \mathrm{C}$, and maintained isothermally for $3 \mathrm{~min}$. Identification was made based on CHOL and 7DHC standard solutions. Quantization was carried out by comparison to ergosterol standard.

\section{Electrophysiology}

Whole-cell measurements were carried out using Axopatch200A/B amplifiers connected to personal computers using Axon Digidata 1440 digitizers. For data acquisition and analysis the pClamp10 software package (Molecular Devices, Sunnyvale, CA) were used. $\mathrm{CD} 4^{+} \mathrm{T}$ lymphocytes were selected for current recording by incubation with mouse anti-human CD4 antibodies $\left(0.5 \mu \mathrm{g} / 10^{6}\right.$ cells, AMAC, Westbrook $)$, followed by selective adhesion to petri dishes coated with goat anti-mouse IgG antibody (Biosource, Camarilo, CA), as described previously [39]. Standard whole-cell patch clamp techniques were used, as described previously [28]. Pipettes were pulled from GC 150F-15 borosilicate glass capillaries (Clark Biomedical Instruments, UK) in four stages and firepolished to give electrodes of 3-6 M $\Omega$ resistance in the bath. The standard bath solution (S-ECS) was (in $\mathrm{mM}$ ) $145 \mathrm{NaCl}, 5$ $\mathrm{KCl}, 1 \mathrm{MgCl}_{2}, 2.5 \mathrm{CaCl}_{2}, 5.5$ glucose, 10 HEPES ( $\mathrm{pH} 7.35$, $305 \mathrm{mOsm}$ ). The pipette solution was (in $\mathrm{mM}$ ) $140 \mathrm{KF}, 11$ $\mathrm{K}_{2}$ EGTA, $1 \mathrm{CaCl}_{2}, 2 \mathrm{MgCl}_{2}$, and10 HEPES (pH 7.20, $\sim 295$ mOsm). To study activation kinetics of Kv1.3, T cells were depolarized to $50 \mathrm{mV}$ for 15 or $30 \mathrm{~ms}$ from a holding potential $-120 \mathrm{mV}$. Kv1.3 current traces were fitted with a single exponential function rising to the maximum according to the Hodgkin-Huxley model $\left(I(t)=I_{a} \times\left(1-\exp \left(-t / \tau_{a}\right)\right)^{4}+C\right.$, where $I_{a}$ is the amplitude of the activating curve component, $\tau_{a}$ is the activation time constant of the current, $C$ is the current amplitude at $-120 \mathrm{mV}$ ). The activation time constant for a particular cell was defined as the average of time constants obtained for at least three depolarizing pulses repeated at every $15 \mathrm{~s}$ in a sequence. We recorded at least four cells of a given patient or donor, and the average of the activation time constants was used to demonstrate the activation kinetics of control and SLOS groups. To study the inactivation of Kv1.3 channels, 2-s-long step pulses to $+40 \mathrm{mV}$ from a holding of $-120 \mathrm{mV}$ were applied to the cells. The fast activation of outward current is followed by a relatively slow decay of current corresponding to the C-type inactivation of this channel. The decaying part of the current traces was fitted with a single exponential function $\left(I(t)=I_{0} \times \exp \left(-t / \tau_{i n, i}\right)+C\right.$, wher $I_{0}$ is the amplitude of current, $\tau_{i n, i}$ is the inactivation time constant for different groups, and $C$ is the steady-state value of whole-cell current at the end of the pulse) to attain the time constant characterizing the inactivation kinetics. The characteristic inactivation time constant for a given cell was determined as detailed for the activation kinetics. Membrane potential dependence of steady-state activation of the Kv1.3 current was determined as follows: cells were held at $-120 \mathrm{mV}$ and depolarized to gradually increasing test potentials. Peak whole-cell conductance $(\mathrm{G}(\mathrm{V}))$ at each test potential was calculated from the peak current $\left(I_{\text {peak }}\right)$ at a test potential $\mathrm{V}$ and the $\mathrm{K}^{+}$reversal potential $\left(\mathrm{E}_{\mathrm{K}}\right)$ using $G(V)=I_{\text {peak }} /\left(V_{\text {test }}-E_{r}\right)$. The $G(V)$ values were normalized for the maximum 
conductance $\left(G_{\text {norm }}\right)$ and plotted as a function of test potential along with the best-fit Boltzmann function $\left(G_{\text {norm }}=1 /(1+\exp \right.$ $\left[-\left(V-V_{1 / 2}\right) / k\right]$, where $G_{\text {norm }}$ is the normalized conductance, $V$ is the test potential, $V_{1 / 2}$ is the midpoint, and $k$ is the slope of the function). We calculated the steady-state parameters at least four individual cells from each donor. The whole-cell membrane capacitance $(C)$ setting on the amplifier required to cancel the transient charging currents evoked by periodic application of $5 \mathrm{mV}$ test pulses was considered as the membrane capacitance of the cells.

\section{DHC and CHOL loading of $\mathrm{T}$ cell membrane}

Freshly isolated control (healthy) lymphocytes were washed twice with Hanks' solution and suspended in Hanks' solution $\left(2 \times 10^{6}\right.$ cells $\left./ \mathrm{ml}\right)$ containing different concentrations of methyl- $\beta$-cyclodextrin/7-DHC (M $\beta \mathrm{CD} / 7 \mathrm{DHC}$, kind gift of Lajos Szente, CycloLab Cyclodextrin Research and Development Laboratory Ltd., Hungary) or methyl- $\beta$-cyclodextrin/CHOL ( $\mathrm{M} \beta \mathrm{CD} / \mathrm{C}$, CycloLab Cyclodextrin Research and Development Laboratory Ltd., Hungary). In control experiments $\mathrm{M} \beta \mathrm{CD} / 7 \mathrm{DHC}, \mathrm{M} \beta \mathrm{CD} / \mathrm{C}$ was not present in the solution. Cell suspensions were incubated for $1 \mathrm{~h}$ at $37{ }^{\circ} \mathrm{C}$ and washed three times with Hanks' solution.

\section{CD154 expression detection}

Previously isolated control and SLOS mononuclear cells were stimulated with thapsigargin $(1 \mu \mathrm{M})$ for $3 \mathrm{~h}$ at $37^{\circ} \mathrm{C}$. For flow cytometry, cells were labeled with phycoerythrin conjugated mouse anti-CD3 antibody (PE-CD3) and Alexa-488 conjugated mouse anti-CD154 antibody (A488-CD154) and there isotype control for $20 \mathrm{~min}$ at room temperature according to the manufacturer's protocol (Biolegend; San Diego; CA). After the staining procedure, the fluorescence intensity of $T$ cells was assessed by BD FacsScan flow cytometer (BecktonDickinson, NJ, USA). In all experiments, at least 10,000 events were recorded and analyzed using FCS Express 4 software. Dead cells were excluded by gating based on side and forward scatter.

\section{CFSE staining and analysis}

To study proliferation of lymphocytes, we applied the modified version of carboxyfluorescein succinimidyl ester (CFSE) dilution essay, originally described by Lyons et al. [36-38, 43]. The final concentration of CFDA-SE (CellTrace $^{\mathrm{TM}}$ CFSE Cell Proliferation Kit, Life Technologies Co., Waltham, MA, USA) was $1 \mu \mathrm{M}$ that provided a 100- to1000-fold increase in the fluorescence intensity of the loaded cells compared to the autofluorescence of unstained cells. We applied $500 \mathrm{ng} / \mathrm{ml}$ soluble anti-CD3 antibodies combined with $1 \mu \mathrm{g} / \mathrm{ml}$ soluble mouse anti-human CD28 (Sigma-Aldrich Co., Saint Louis, MO, USA) for specific T cell stimulation in the mononuclear cell cultures. The flow cytometry analysis was performed on a BD FACScan ${ }^{\mathrm{TM}}$ cytometer. Fluorescence gate settings for lymphocytes are shown on Fig. 7 a, b. Lymphocytes were selected from mixed cell populations of PBMC by their light scatter profile on FACS analysis (Fig. 7a). Cell proliferation was determined based on the decreasing CFSE intensity in the green channel (Fig. 7c). The indicator of proliferation was the division index (DI), calculated by the following formula:

$D I=\left(\sum_{k=1}^{n} A_{k}\right) /\left(\sum_{k=0}^{n} A_{k}\right)$

where $k$ points to the $n$th generation of cells, and $A_{k}$ is the cell number in the $k$ th division cycle according to Fig. 7c.

\section{Data analysis}

Prior to analysis whole-cell current traces were corrected for ohmic leak. Nonlinear least squares fits were done using the Levenberg-Marquardt algorithm. Fits were evaluated visually as well as by the residuals and the sum of squared differences between the measured and calculated data points. Data are expressed as mean \pm SEM. For pairwise comparisons Student's $t$ test or Mann-Whitney rank sum test (nonnormal distribution population) were applied. For multiple comparisons, one-way or two-way ANOVA with post hoc HolmSidak (HS) test were used. Statistical significance was taken as $p<0.05$ (* indicates statistical difference) or $p<0.001$ (** indicates statistical difference).

\section{Results}

\section{Sterol composition of SLOS membrane}

We characterized the sterol profile of the red blood cells (RBCs) from SLOS patients and age-matched control donors in order to gain information regarding the alteration of the sterol environment, and especially that of the $7 \mathrm{DHC} / \mathrm{CHOL}$ ratio in the cell membrane induced by the SLOS disease [16, 61]. Table 1 shows the elevated 7DHC and reduced CHOL levels in all of the SLOS samples, while 7DHC in the control samples was undetectable. $8 \mathrm{DHC}$, which is a common isomer of $7 \mathrm{DHC}$, was also identified in every SLOS sample (data not shown) [8]. Results of the RBC sterol composition analysis are comparable to the comprehensive study by Russo et al. [16]. 
Table $17 \mathrm{DHC}$ and $\mathrm{CHOL}$ composition of SLOS and control red blood cells

\begin{tabular}{lllll}
\hline \multirow{2}{*}{ Sample } & Clinical severity type & \multicolumn{3}{l}{ Membrane sterols (nmol/L) } \\
\cline { 3 - 5 } & & CHOL & $7 \mathrm{DHC}$ & 7DHC/CHOL \\
\cline { 3 - 5 } & & 0.93 & 0.10 & 0.11 \\
\hline SLO\#1 & $\mathrm{M}$ & 1.23 & 0.30 & 0.25 \\
SLO\#2 & $\mathrm{M}$ & 1.48 & 0.11 & 0.08 \\
SLO\#3 & $\mathrm{M}$ & 1.73 & 0.93 & 0.54 \\
SLO\#4 & $\mathrm{T}$ & 3.44 & 0.53 & 0.16 \\
SLO\#5 & $\mathrm{T}$ & 0.13 & 0.76 & 5.63 \\
SLO\#6 & $\mathrm{T}$ & 0.10 & 0.67 & 6.47 \\
SLO\#7 & $\mathrm{T}$ & $1.29 \pm 1.14$ & $0.49 \pm 0.32$ & $1.89 \pm 2.86$ \\
Mean \pm SEM & - & 5.08 & $\mathrm{ND}$ & - \\
Control\#1 & - & 4.75 & $\mathrm{ND}$ & - \\
Control\#2 & - & 4.36 & $\mathrm{ND}$ & - \\
Control\#3 & - & 4.83 & $\mathrm{ND}$ & - \\
Control\#4 & - & 2.46 & $\mathrm{ND}$ & - \\
Control\#5 & - & $4.3 \pm 0.47$ & & \\
Mean \pm SEM & - & & & \\
\hline
\end{tabular}

$R B C$ red blood cell, $C H O L$ cholesterol, $7 D H C$ 7-dehydrocholesterol, $N D$ not detectable, $M$ mild, $T$ typical

\section{Expression level of Kv1.3 channels in SLOS $\mathrm{T}$ cells is similar to that in healthy donors}

Since Kv1.3 channel is the main voltage-gated $\mathrm{K}^{+}$channel of T lymphocytes and plays pivotal role in regulating of the proliferation of T cells, we examined the expression and biophysical properties of Kv1.3 channels in SLOS patients. Current density (CuD: the peak current normalized to membrane capacitance, proportional to the number of channels per unit area) provides information about the impact of the channels on the membrane potential control of the cell, since a given number of channels regulate the membrane potential more readily in a smaller cell than in a larger one. $\mathrm{T}$ cells were held at $-120 \mathrm{mV}$ (holding potential) and depolarized to $+50 \mathrm{mV}$ for $15 \mathrm{~ms}$ in whole-cell configuration to determine whole cell peak currents $\left(I_{p}\right)$, then $I_{p}$ of an individual cell was divided by the membrane capacitance (C) of the particular cell to calculate current density. Whole-cell peak currents and whole-cell membrane capacitance were the same in control and SLOS groups, and there was no statistical significant difference between the current densities of control and SLOS T cells (see Fig. 1 and Table 2).

\section{Slowing of Kv1.3 current kinetics in SLOS T cells}

We previously demonstrated that the increase of CHOL content of the T cell membrane influenced the gating kinetics of
Fig. 1 Expression level of Kv1.3 in SLOS. a The average wholecell current (WCC), $\mathbf{b}$ whole-cell capacitance (C), and $\mathbf{c}$ current density $(\mathrm{CuD})$ for the control and SLOS donors. Error bars represent SEM
A
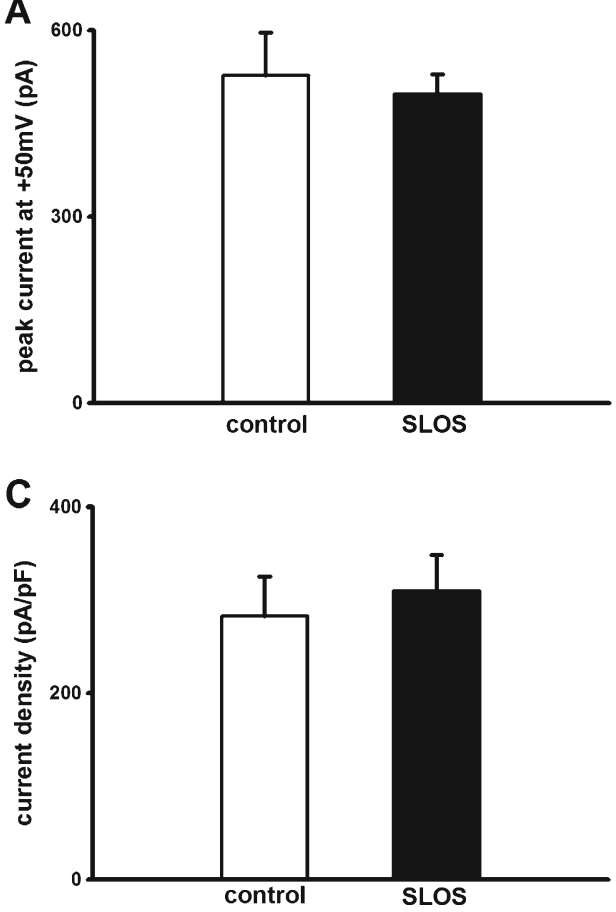

B

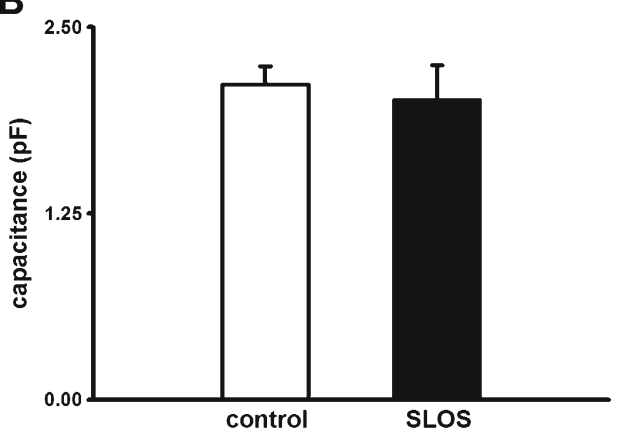


Table 2 Parameters of Kv1.3 currents recorded from healthy subjects and SLOS patients

\begin{tabular}{llll}
\hline Kv1.3 current parameter & Healthy subject (Control) & SLOS patient & $p$ value \\
\hline Peak current (pA) & $528.0 \pm 69(n=56)$ & $497.5 \pm 31(n=51)$ & 0.7 \\
Membrane capacitance (pF) & $2.1 \pm 0.1(n=56)$ & $2.0 \pm 0.2(n=51)$ & 0.69 \\
Current density (pA/pF) & $282.5 \pm 42.9(n=56)$ & $309.8 \pm 39(n=51)$ & 0.65 \\
Activation time constant (ms) & $0.59 \pm 0.02(n=56)$ & $0.75 \pm 0.03(n=51)$ & $0.001^{*}$ \\
Inactivation time constant (ms) & $227.8 \pm 14.2(n=38)$ & $253.7 \pm 21.4(n=45)$ & 0.327 \\
$V_{1 / 2}(\mathrm{mV})$ & $-26.9 \pm 0.9(n=41)$ & $-22.0 \pm 1.9(n=35)$ & $0.03^{*}$ \\
$k(\mathrm{mV})$ & $11.7 \pm 0.5(n=41)$ & $10.6 \pm 0.5(n=35)$ & 0.14 \\
\hline
\end{tabular}

$V_{1 / 2}$ midpoint of steady-state activation, $k$ slope factor of the steady-state activation

*Statistical difference with $p<0.05$
Kv1.3 [27]. To study whether the altered sterol profile in SLOS affects the kinetic properties of Kv1.3 current, we recorded Kv1.3 whole-cell currents of T lymphocytes isolated from SLOS patients and control (age-matched healthy) donors. Figure 2a shows normalized current traces evoked in a control and an SLOS T lymphocyte upon depolarization to $+50 \mathrm{mV}$. The activation time constant $\left(\tau_{a}\right)$ (see "Material and methods") was significantly greater for SLOS cells, i.e., the kinetics of channel opening is slower in SLOS lymphocytes (Fig. 2a, d and Table 2). Figure $2 \mathrm{~b}$ illustrates normalized current traces recorded during 2-s-long step pulses to $+40 \mathrm{mV}$ : the fast rising of the current is followed by a relatively slow decay, which corresponds to the C-type inactivation of Kv1.3 channels. By fitting a single-exponential function to the declining part of these curves, we obtained the inactivation time constants (see "Material and methods"), which did not show significant increase (Fig. 2e and Table 2).

\section{SLOS modifies the membrane potential dependence of steady-state activation}

As the kinetics of the Kv1.3 gating was affected by the increased 7DHC level, we also investigated the equilibrium parameters of Kv1.3 activation. Figure $2 \mathrm{c}$ displays $G_{\mathrm{norm}}-V$ plots for an SLOS and a control $\mathrm{T}$ cell along with the best-fit Boltzmann curves (for details, see "Material and methods"): the sigmoid curve of the voltage dependence of steady-state activation for SLOS patient is rightward shifted as compared to the control (Fig. 2c). Comparison of the equilibrium activation parameters showed that the midpoint of the curve $\left(V_{1 / 2}\right.$, the membrane potential at which $50 \%$ of the channels is open at steady state) is significantly more positive for SLOS T cells without a statistically significant change in the slope factor (Fig. 2f and Table 2).

\section{Modeling 7DCH/CHOL ratio of the SLOS membrane in T cell}

To verify if 7DHC incorporation into the $\mathrm{T}$ cell membrane affects Kv1.3 function, we created an SLOS-like sterol environment by modification of the 7DHC content of healthy $\mathrm{T}$ cells with $\mathrm{M} \beta \mathrm{CD} / 7 \mathrm{DHC}$ complex in vitro. To validate the incorporation of 7DHC into the plasma membrane, untreated and $\mathrm{M} \beta \mathrm{CD} / 7 \mathrm{DHC}$ treated PBMCs were subjected to GC-MS analysis. Figure 3 a shows that the amount of 7DHC in the cell membrane increases gradually with the higher applied concentration of $\mathrm{M} \beta \mathrm{CD} / 7 \mathrm{DHC}$ (7DHC level normalized to protein content was $26.1 \pm 1.0 \mu \mathrm{g} / \mathrm{mg}$ for $65 \mu \mathrm{M} \mathrm{M} \beta \mathrm{CD} / 7 \mathrm{DHC}$ and $66.8 \pm 11 \mu \mathrm{g} / \mathrm{mg}$ for $195 \mu \mathrm{M} \mathrm{M} \beta \mathrm{CD} / 7 \mathrm{DHC}$ ). Parallel to the increase in $\mathrm{M} \beta \mathrm{CD} / 7 \mathrm{DHC}$, the $\mathrm{CHOL}$ content showed decreasing tendency, which can be due to the $\mathrm{CHOL}$ removal by the empty $\mathrm{M} \beta C D$, but the change was not significant as compared to the untreated group (CHOL level normalized to protein amount was $18.3 \pm 3.7 \mu \mathrm{g} / \mathrm{mg}$ for control, 16.2 $\pm 0.2 \mu \mathrm{g} / \mathrm{mg}$ for $65 \mu \mathrm{M} \mathrm{M} \beta \mathrm{CD} / 7 \mathrm{DHC} ; 13.3 \pm 2 \mu \mathrm{g} / \mathrm{mg}$ for $195 \mu \mathrm{M} \mathrm{M} \beta \mathrm{CD} / 7 \mathrm{DHC})$. These clearly showed that membrane 7DHC and CHOL ratio is similar to those described in SLOS patients.

\section{Biophysical properties of Kv1.3 in 7DHC-loaded T cells resemble those observed in SLOS}

Next, we characterized the kinetic and equilibrium parameters of Kv1.3 gating in the 7DHC-loaded $\mathrm{CD}^{+}{ }^{+} \mathrm{T}$ cells. First, the activation kinetics of Kv1.3 channels was measured for 7DHC-loaded cells and we found that activation kinetics became slower as the 7DHC level increased in the membrane (Fig. 3b, d, Table 3). For the inactivation kinetics, we found that the time constant increased compared to untreated cells (Table 3). Finally, the voltage dependence of steady-state activation was evaluated for $\mathrm{T}$ cells treated with different amounts of $\mathrm{M} \beta \mathrm{CD} / 7 \mathrm{DHC}$ : just as described for SLOS cells, the midpoint of activation, i.e., the half-maximal voltage was shifted to the positive voltages (Fig. 3c, e and Table 3) but slope factor did not change (Fig. 3e, Table 3). These data together suggest that the change of the membrane 7DHC content can be responsible for the altered Kv1.3 function in SLOS. Current density, whole-cell peak current, and membrane capacitance were also determined for 32.5, 65, and $195 \mu \mathrm{M} \mathrm{M} \beta \mathrm{CD} / 7 \mathrm{DHC}$ treatments. Although membrane 


\section{A}
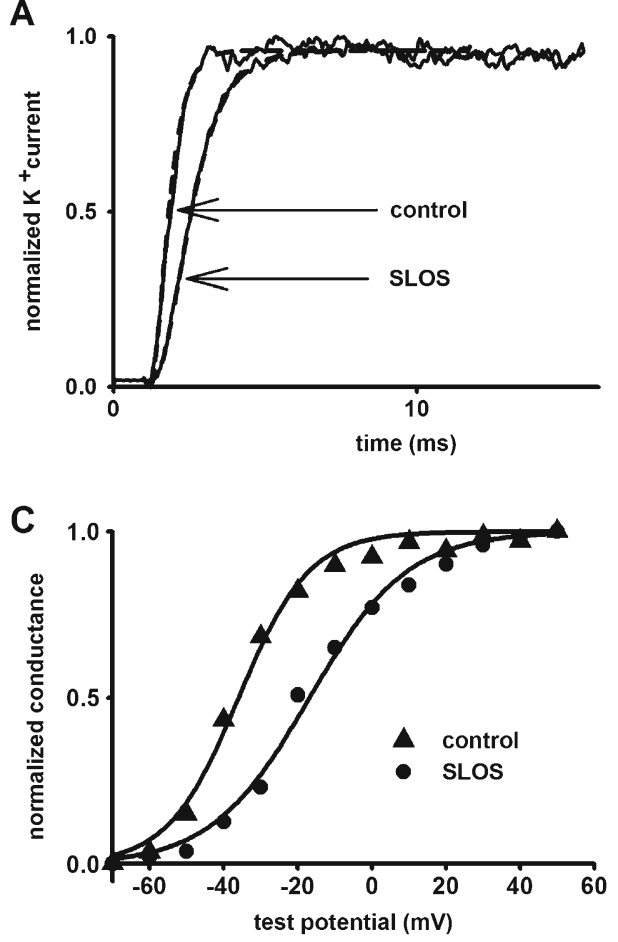

E

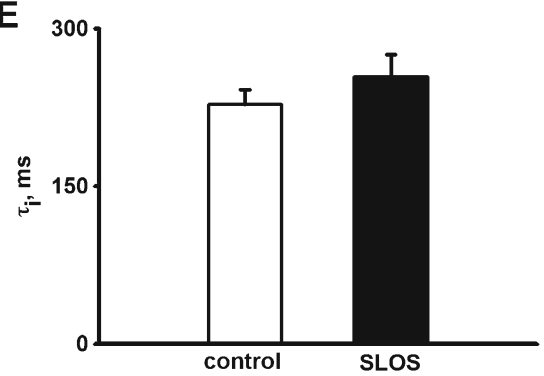

Fig. 2 Activation of Kv1.3 channels is modified in SLOS T cells. a To study the kinetic properties of activation of $\mathrm{Kv} 1.3$, T cells were depolarized to $+50 \mathrm{mV}$ from $-120 \mathrm{mV}$ for $15 \mathrm{~ms}$. Normalized current traces evoked in an SLOS and a control T cells are shown with the best-fit curves using Hodgkin-Huxley $\mathrm{n}^{4}$ - modell (see "Material and methods"). b To study the inactivation of the Kv1.3 current T cells were depolarized to $+40 \mathrm{mV}$ for $2 \mathrm{~s}$ from a holding potential of $-120 \mathrm{mV}$. The representative current traces for a control and an SLOS cell are displayed with the bestfitting single exponential function to the declining phase of the curve (also detailed in the "Material and methods"). c Voltage dependence of equilibrium activation of the Kv1.3 channels in an SLOS (circle) and a

capacitance did not change, the whole-cell peak currents decreased significantly upon the 7DHC loading (Table 3). Consequently, the $\mathrm{M} \beta \mathrm{CD} / 7 \mathrm{DHC}$ loading significantly decreased the current density of Kv1.3 of T cells unlike for those from the SLOS patients (Fig. 3f and Table 3).

\section{Comparison of CHOL and 7DHC loading}

In our previous study, we demonstrated that in vitro loading of CHOL slowed the kinetics and modified the steady-state parameters of Kv1.3 gating. Similar changes in the biophysical
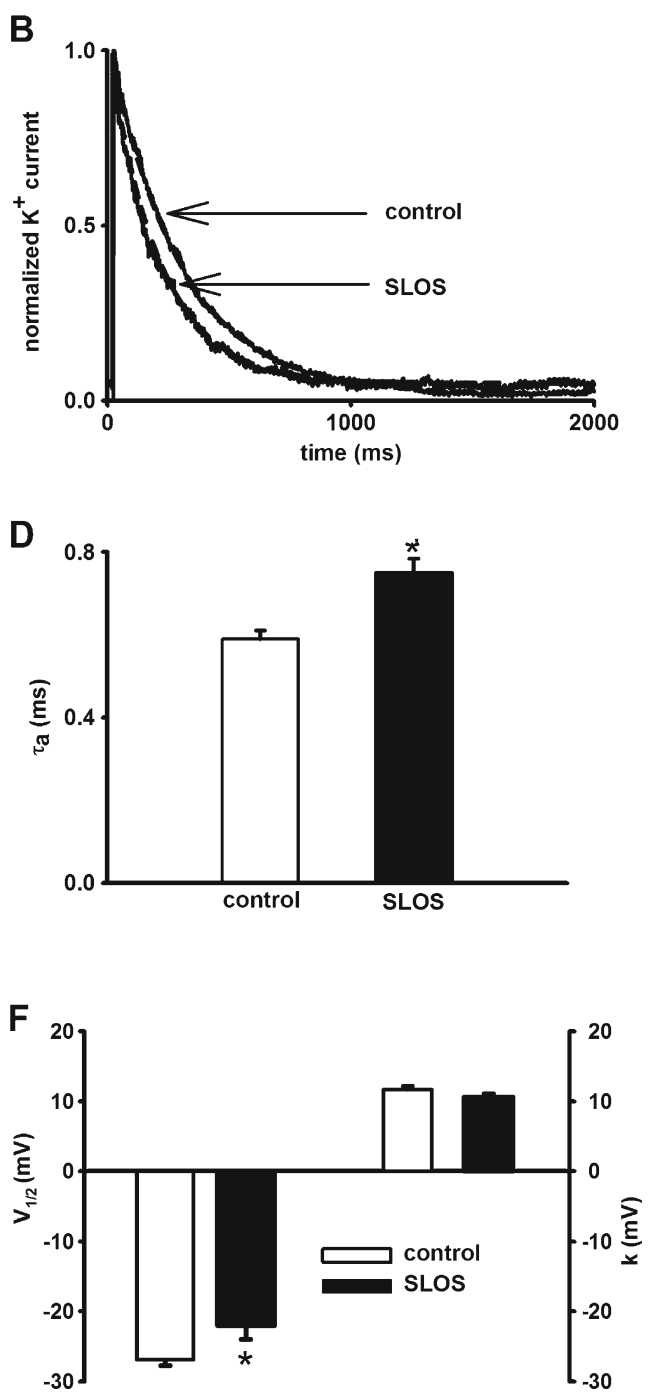

healthy (triangles) T cell along with the best-fit Boltzmann functions is illustrated. The normalized conductance test potential relationships $\left(G_{\text {norm }}-V\right.$ plot) were obtained and analyzed as described in the "Material and methods." d, e The activation ( $n=56,8$ donors for control; $n=44,8$ patients for SLOS) and inactivation ( $n=38,8$ donors for control; SLOS: $n=45,8$ patients) time constants for Kv1.3 currents in SLOS and control T cells. (mean $\pm \mathrm{SEM},{ }^{*}$ statistical difference at $p=0.05$ ). $\mathbf{f}$ Parameters of steady-state activation (slope $(k)$ and midpoint $\left.\left(V_{1 / 2}\right)\right)$ are shown for the Kv1.3 channels in SLOS and control T cells (mean \pm SEM, control: $n=41,8$ donors; SLOS: $n=38,8$ patients, ${ }^{*}$ statistical difference at $p=0.05))$

parameters of Kv1.3 gating were found in the current study in SLOS and SLOS model system [26]. These results raised the question whether the effect of 7DHC and CHOL loading are quantitatively similar or different. Therefore, we treated the $\mathrm{T}$ cells with the same concentration of CHOL and 7DHC and measured the biophysical properties of Kv1.3. We found that $\mathrm{Kv} 1.3$ is more sensitive to $7 \mathrm{DHC}$ than $\mathrm{CHOL}$ loading at $32.5 \mu \mathrm{M}$ : 7DHC significantly increased the activation time constant and shifted $\mathrm{V}_{1 / 2}$ toward positive voltages, whereas CHOL did not (Fig. 4a, d and Table 3). At higher concentrations of $\mathrm{M} \beta \mathrm{CD} / 7 \mathrm{DHC}$ and $\mathrm{M} \beta \mathrm{CD} / \mathrm{CHOL}$ both compounds 
Fig. 3 7DHC loading mimics SLOS in T cells. a GC-MS analysis of CHOL and 7DHC level in $\mathrm{M} \beta \mathrm{CD} / 7 \mathrm{DHC}$ treated ( 65 and $195 \mu \mathrm{M})$ control

lymphocytes (from healthy agematched donors). $\mathrm{M} \beta \mathrm{CD} / \mathrm{CHOL}$ treatment $(140 \mu \mathrm{M})$ was applied as a positive control. b Current traces of Kv1.3 activation are shown for 7DHC-loaded cells; same protocol was applied as in Fig. 2a. c Normalized conductance of Kv1.3 current is plotted as a function of the membrane-potential (see "Material and methods" and Fig 2c) for $\mathrm{M} \beta \mathrm{CD} / 7 \mathrm{DHC}$ treated cells; the fitted Boltzmann curves are also shown. d, e The activation time constant and the parameters of equilibrium activation are shown ( $n>7$ for each treatment). f Current density $(\mathrm{CuD})$ of 7DHC loaded cells (mean \pm SEM, $n>7$ ); * and ** indicate statistical difference at $p=0.05$ and $p=0.01$, respectively
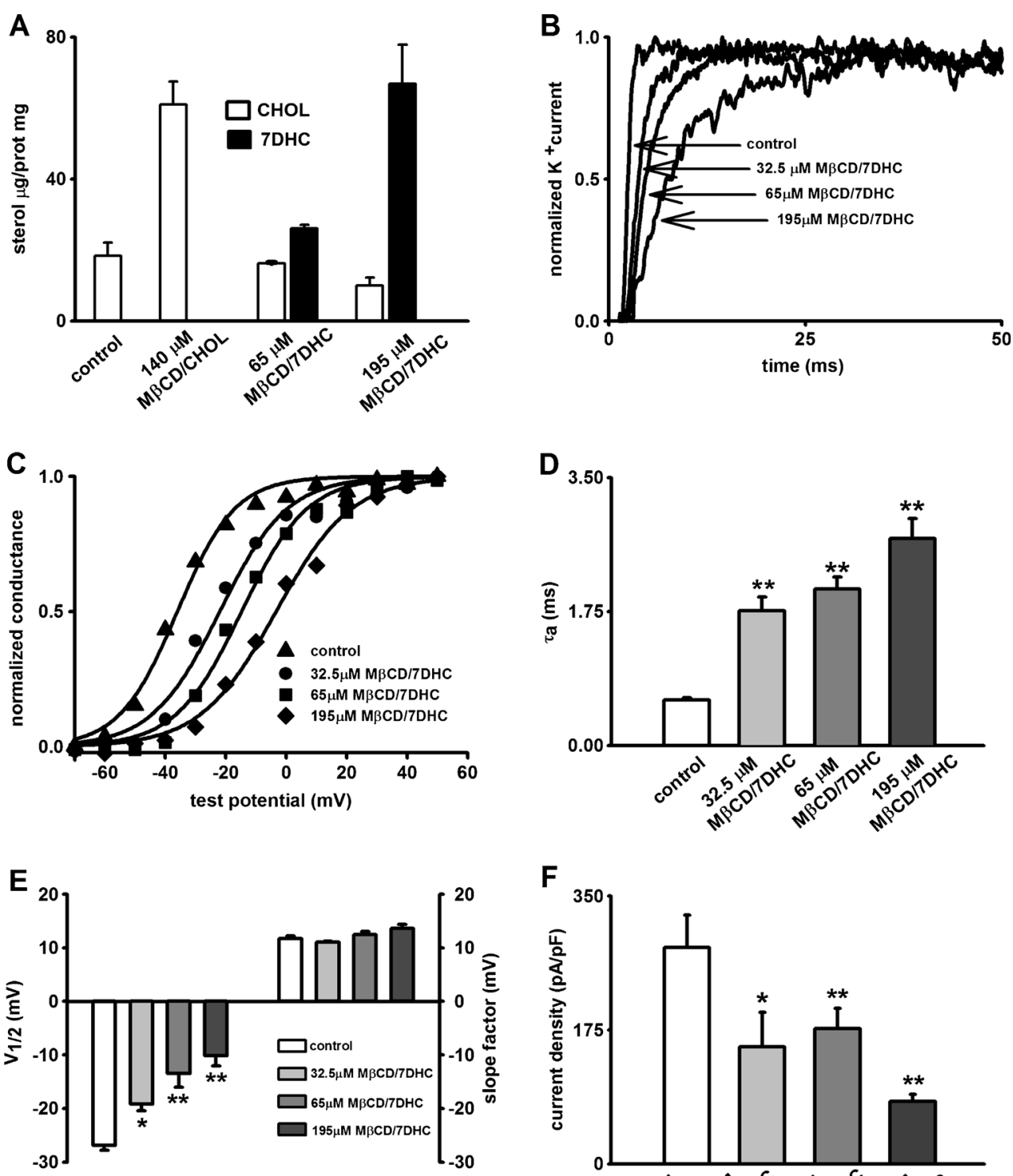

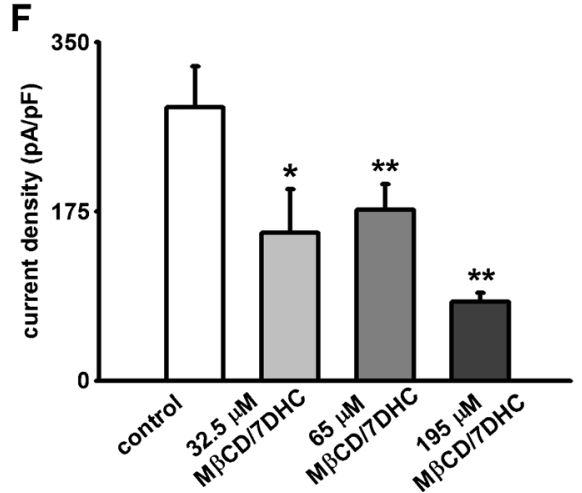

changed the kinetic and steady-state parameters of Kv1.3 gating but $195 \mu \mathrm{M} \mathrm{M} \beta \mathrm{CD} / 7 \mathrm{DHC}$ was more effective in changing $\mathrm{V}_{1 / 2}$ than equimolar $\mathrm{M} \beta \mathrm{CD} / \mathrm{CHOL}$ (Fig. $4 \mathrm{~b}$, c, e, f and Table 3). Our results suggest that $\mathrm{CHOL}$ and $7 \mathrm{DHC}$ influence channel function in a very similar way, however, due to their structural difference their capacity to modify the operation of an ion channel could be distinctive.

\section{Removal of the cytoplasmic C-terminal of Kv1.3: loss of sensitivity to sterol loading}

We tested the effect of CHOL and 7DHC loading on a Cterminal-deleted Kv1.3 channel (mGFP-Kv1.3 $\Delta$ C), which lacks the last 84 amino acid residues at its $\mathrm{C}$-terminal and consequently lacks the two CARC sequences recently identified on other ion channels as specific CHOL receptor sites being responsible for the effect of sterols on ion channels $[20,34,49,52]$. If CHOL and 7DHC acts on these proposed receptor sites then $\mathrm{Kv} 1.3 \Delta \mathrm{C}$ should be CHOL and 7DHC insensitive. Previously, we showed that biophysical characteristics of the mGFP-Kv1.3-WT and mGFP-Kv1.3 $\Delta \mathrm{C}$ are identical; removal of the C-terminal did not change significantly the gating properties of Kv1.3 [57]. mGFP-Kv1.3-WT and mGFP-Kv1.3 $\Delta \mathrm{C}$ expressing $\mathrm{CHO}$ cells were loaded using $420 \mu \mathrm{M} \mathrm{CHOL}$ and 7DHC, and ionic currents were measured in outside-out patch configuration. As expected, $420 \mu \mathrm{M}$ CHOL or 7DHC shifted the midpoint of the voltage dependence of steady-state activation and increased the activation time constant in case of the mGFP-Kv1.3-WT CHO cells $\left(V_{1 / 2, \mathrm{WT}}:-28.9 \pm 1.5\right.$ for control and $-17.5 \pm 1.9 \mathrm{mV}$ for 
$420 \mu \mathrm{M}$ CHOL, $p<0.001 ;-19.3 \pm 4.7 \mathrm{mV}, p=0.028$ for $420 \mu \mathrm{M}$ 7DHC; $\tau_{a, \mathrm{WT}}: 0.45 \pm 0.01 \mathrm{~ms}$ for control, 0.76 $\pm 0.02 \mathrm{~ms}$ for $420 \mu \mathrm{M} \mathrm{M} \beta \mathrm{CD} / \mathrm{CHOL}, p=0.002 ; 0.69$ $\pm 0.06 \mathrm{~ms}$ for $420 \mu \mathrm{M} \mathrm{M} \beta \mathrm{CD} / 7 \mathrm{DHC}, p=0.008$, Fig. $5 \mathrm{a}$, c.) On the contrary, mGFP-Kv1.3 $\Delta \mathrm{C}$ channels were insensitive to both $\mathrm{CHOL}$ and $7 \mathrm{DHC}$ loading $\left(V_{1 / 2, \Delta \mathrm{C}}:-26.7 \pm 2.7 \mathrm{mV}\right.$ for control; $V_{1 / 2, \Delta \mathrm{C}}:-26.3 \pm 2.7 \mathrm{mV}$ for $420 \mu \mathrm{M} \mathrm{M} \beta \mathrm{CD} / \mathrm{CHOL}$, $p>0.05 ; V_{1 / 2, \Delta \mathrm{C}}:-23.1 \pm 1.1 \mathrm{mV}$ for $420 \mu \mathrm{M} \mathrm{M} \beta \mathrm{CD} / 7 \mathrm{DHC}$, $p>0.05$ ); and $\tau_{a, \Delta C}: 0.59 \pm 0.04 \mathrm{~ms}$ for control, $0.55 \pm 0.02 \mathrm{~ms}$ for $420 \mu \mathrm{M} \mathrm{M} \beta \mathrm{CD} / \mathrm{CHOL}, p>0.05 ; 0.65 \pm 0.04 \mathrm{~ms}$ for $420 \mu \mathrm{M} \mathrm{M} \beta \mathrm{CD} / 7 \mathrm{DHC}, p>0.05$, Fig. 5b, d).

\section{Activation and proliferation of SLOS T cells is suppressed}

We aimed to study the effects of the altered 7DHC/CHOL ratio on the Kv1.3-dependent biological functions of $\mathrm{T}$ cells such as activation and proliferation. To assess the effect of SLOS on T cell activation, we measured the expression of CD154 of lymphocytes. CD154 is a marker of activation on $T$ lymphocytes stimulated through calcium-triggered NFAT pathways $[1,6]$. We assumed that the modified ion channel function in SLOS influences the Kv1.3-dependent calcium signaling during $\mathrm{T}$ cell activation, which could change the expression of CD154. Mononuclear cells were stimulated with thapsigargin to trigger the calcium-dependent activation pathway and labeled with PE-conjugated anti-CD3 and A488conjugated anti-CD154 antibody. T cells were identified by gating on $\mathrm{CD}^{+}$cells (Fig. 6a, b). Our results indicate that the ratio of $\mathrm{CD} 154^{+} \mathrm{T}$ cells decreased significantly in SLOS compared to the age-matched healthy controls (fraction of CD $154^{+} \mathrm{CD}^{+}$cells in SLOS: $8.6 \pm 3.2 \%$, control: 21.1 $\pm 2.8 \%$, Fig. $6 \mathrm{c}, \mathrm{d}, p<0.001)$. The mean fluorescence intensity (MFI) of SLOS lymphocytes was also reduced, but the difference was not significant (MFI of CD154 in SLOS 15.5 \pm 2.1 a.u.; in control group $20.4 \pm 3.7$ a.u., $p=0.13$ ). We also tested the proliferation capacity of $\mathrm{T}$ cells using the CFSE staining technique, which is a suitable method to observe the proliferation characteristics of lymphocytes with flow cytometry (Fig. 7a, b).We found that the 5-day antiCD3/antiCD28 stimulation (see details in "Material and methods") of T lymphocytes was less effective in SLOS than in the control group (Fig. 7c, d). The division indices of T lymphocytes were 29.4 \pm 3.5 and $61.1 \pm 7.1 \%$ for SLOS and the control group, respectively ( $p=0.002$, Fig. $7 \mathrm{e})$.

\section{Discussion}

In the present study, we reported for the first time that accumulation of 7DHC in the cell membrane modifies the operation of the voltage-gated ion channel Kv1.3 both in SLOS T cells and in T cells acutely loaded with 7DHC $(\mathrm{M} \beta \mathrm{CD} / 7 \mathrm{DHC}$-treated lymphocytes), and also influences 
Fig. $4 \mathrm{Kv} 1.3$ sensitivity to 7DHC- and CHOL-loading is different. Control lymphocytes (from healthy age-matched donors) were loaded with 7DHC and $\mathrm{CHOL}$ at equal concentrations, and activation kinetics and voltage dependence of steady-state activation were investigated as detailed in

Fig. 2a, c. a-c Average activation time constants of Kv1.3 current at $32.5,65$, and $195 \mu \mathrm{M}$

$\mathrm{M} \beta \mathrm{CD} / 7 \mathrm{DHC}$ and

$\mathrm{M} \beta \mathrm{CD} / \mathrm{CHOL}$ concentrations.

d-f Average of the half-maximal voltage for equilibrium activation at treatment with $32.5,65$, and $195 \mu \mathrm{M} \mathrm{M} \beta \mathrm{CD} / 7 \mathrm{DHC}$ and $\mathrm{M} \beta \mathrm{CD} / \mathrm{CHOL}$. Data are presented as mean \pm SEM. * and $* *$ represent significant difference at $p=0.05$ and $p=0.001$, respectively
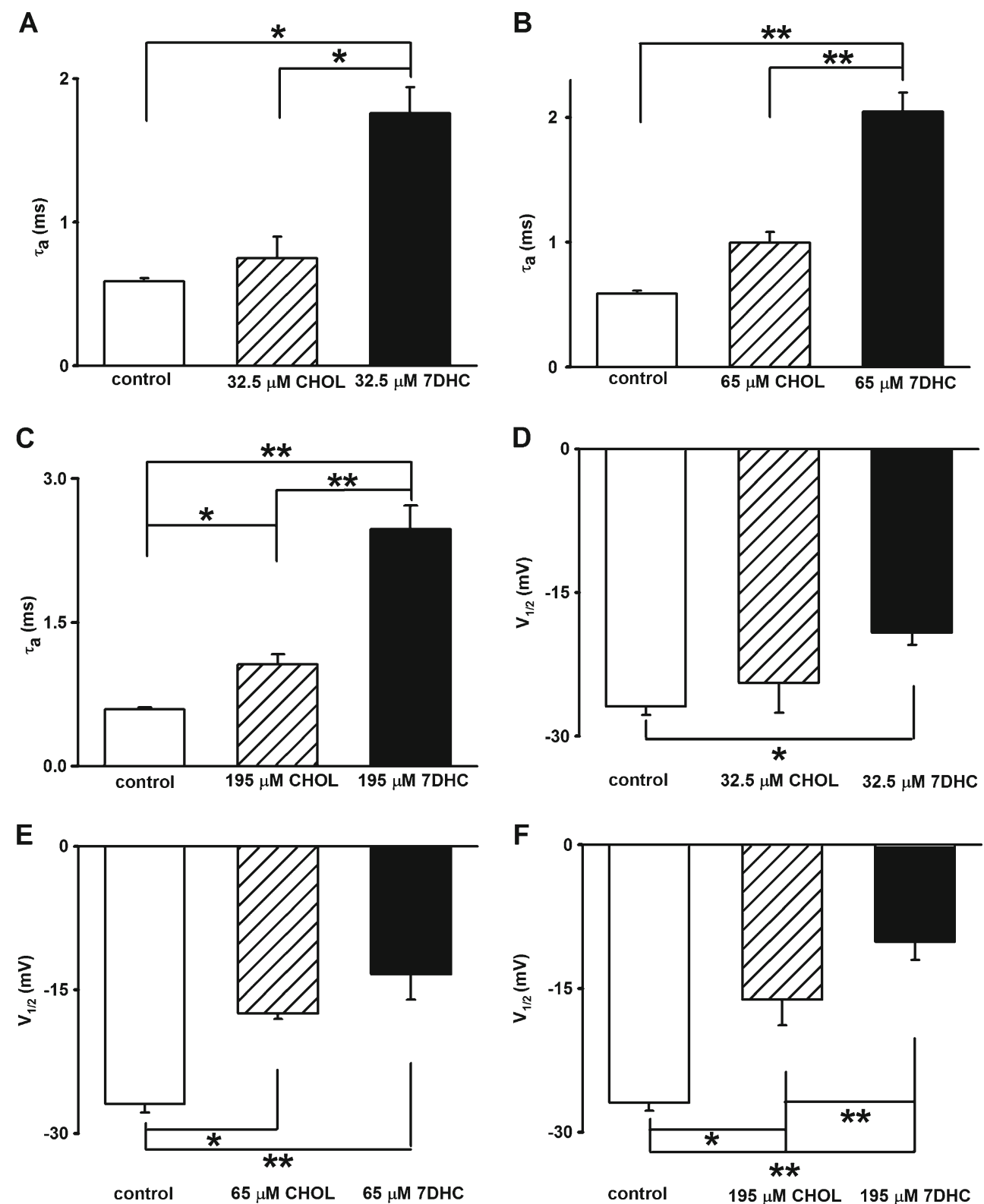

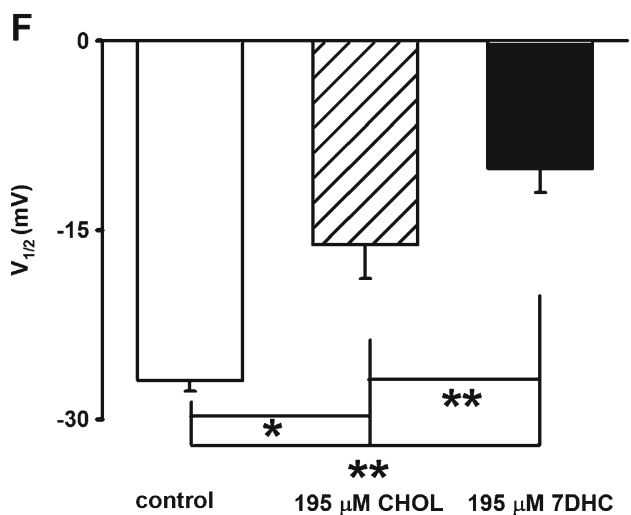

the $\mathrm{Ca}^{2+}$-dependent signaling events coupled to $\mathrm{Kv} 1.3$ activity. We showed that (1) elevated membrane 7DHC level in SLOS T cells modifies the equilibrium and kinetic properties of Kv1.3 activation, (2) $\mathrm{M} \beta \mathrm{CD} / 7 \mathrm{DHC}$ loading of $\mathrm{T}$ cell membrane, which mimics the sterol environment in SLOS, results in similar changes in Kv1.3 gating as described in SLOS, (3) the Kv1.3 construct (Kv1.3 $\Delta \mathrm{C}$ ) lacking the putative sterol-binding sequences on the $\mathrm{C}$ terminus is insensitive to the sterol-modification of the membrane, and (4) the early steps of the $\mathrm{Ca}^{2+}$-dependent $\mathrm{T}$ cell activation pathway as well as the division index of SLOS $\mathrm{T}$ cells is hampered. These data all support that presence of 7DHC in the plasma membrane affects Kv1.3 function and the cellular processes which depend on Kv1.3 activity.
The laboratory medicine profile (i.e., serum sterols) of SLOS patients is quite diverse, a wide range of plasma 7DHC and CHOL concentrations were reported even for genetically homogenous patient groups [16, 42]. Furthermore, the $7 \mathrm{DHC} / \mathrm{CHOL}$ ratios in the plasma and in red blood cells also show significant variations among patients. Therefore, we aimed at confirming that cellular $7 \mathrm{DHC}$ to $\mathrm{CHOL}$ ratios display 7DHC accumulation in our patient group. In the absence of sufficient amount of blood samples for the characterization of the sterol composition of the T cell membrane, we monitored the $7 \mathrm{DHC}$ content as well as the ratio of CHOL/7DHC in RBCs isolated from SLOS patients (Table 1). Our data confirmed a decrease in CHOL and increase in 7DHC levels in the RBCs of every donor (see Table 1) as compared to healthy counterparts. Moreover, 
Fig. 5 Kv1.3 C-terminus is involved in the sterol mediated regulation. $\mathrm{CHO}$ cells stably expressing mGFP-Kv1.3-WT and mGFP-Kv1.3 $\Delta \mathrm{C}$ channels were loaded with $7 \mathrm{DHC}$ and $\mathrm{CHOL}$ (both at $420 \mu \mathrm{M}$ ), and activation kinetics and voltage dependence of steady-state activation were studied as detailed before in

Fig. 2a, c. a, b Average activation time constants for mGFP-KV1.3$\mathrm{WT}$ (a) and mGFP-Kv1.3 $\Delta \mathrm{C}(\mathbf{b})$ current upon $\mathrm{M} \beta \mathrm{CD} / \mathrm{CHOL}$ and $\mathrm{M} \beta \mathrm{CD} / 7 \mathrm{DHC}$ treatment. $\mathbf{c}, \mathbf{d}$ Average half-maximal voltage for steady-state activation of mGFP-Kv1.3-WT (c) and mGFP-Kv1.3 $\Delta \mathrm{C}$ (d) channels upon $\mathrm{CHOL}$ and $7 \mathrm{DHC}$ loading. Bar graphs show mean \pm SEM for $n>5 . *$ and $* *$ represent significant difference at $p=0.05$ and $p=0.001$, respectively
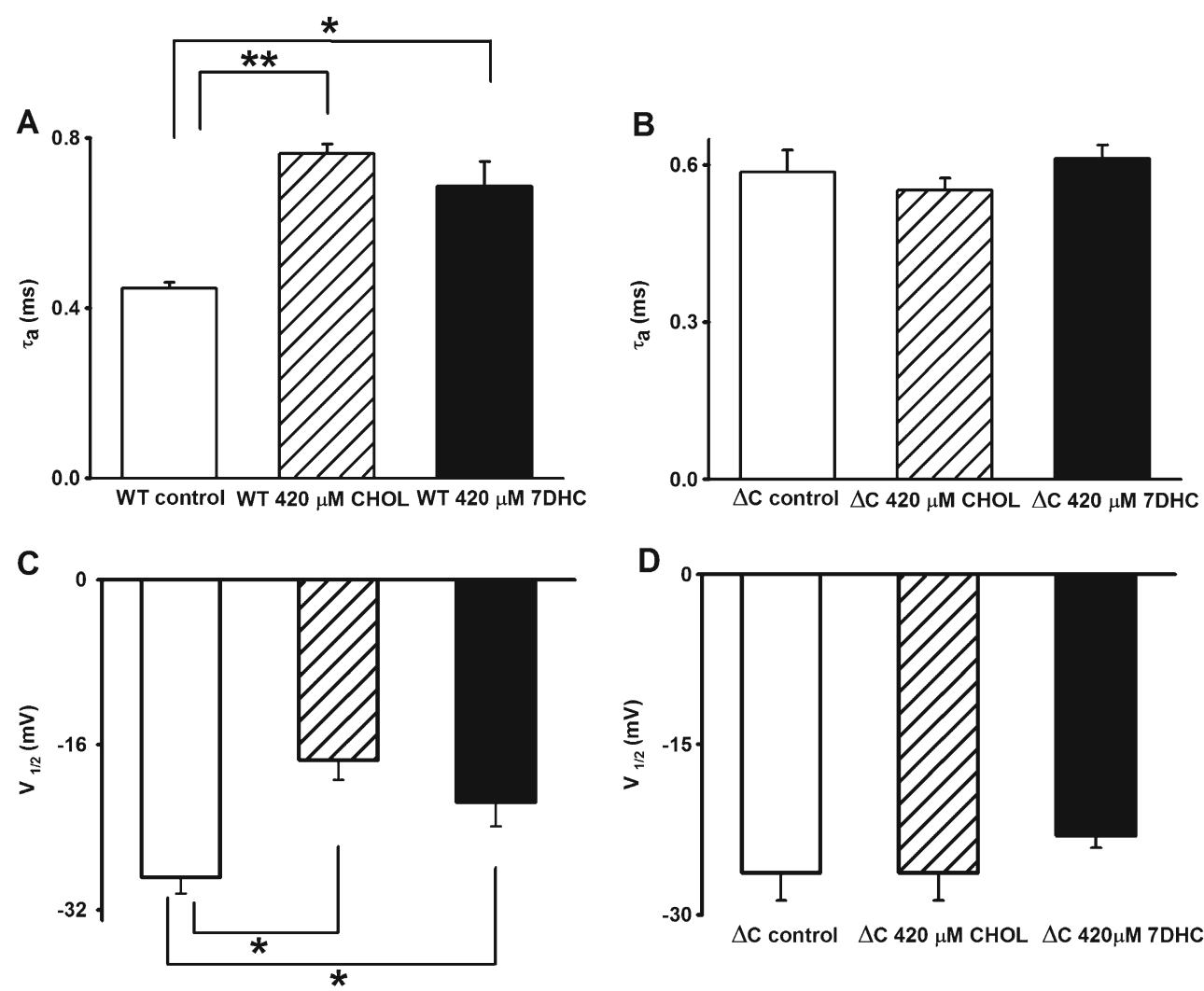

WT control WT $420 \mu \mathrm{M}$ CHOL WT $420 \mu \mathrm{M}$ 7DHC
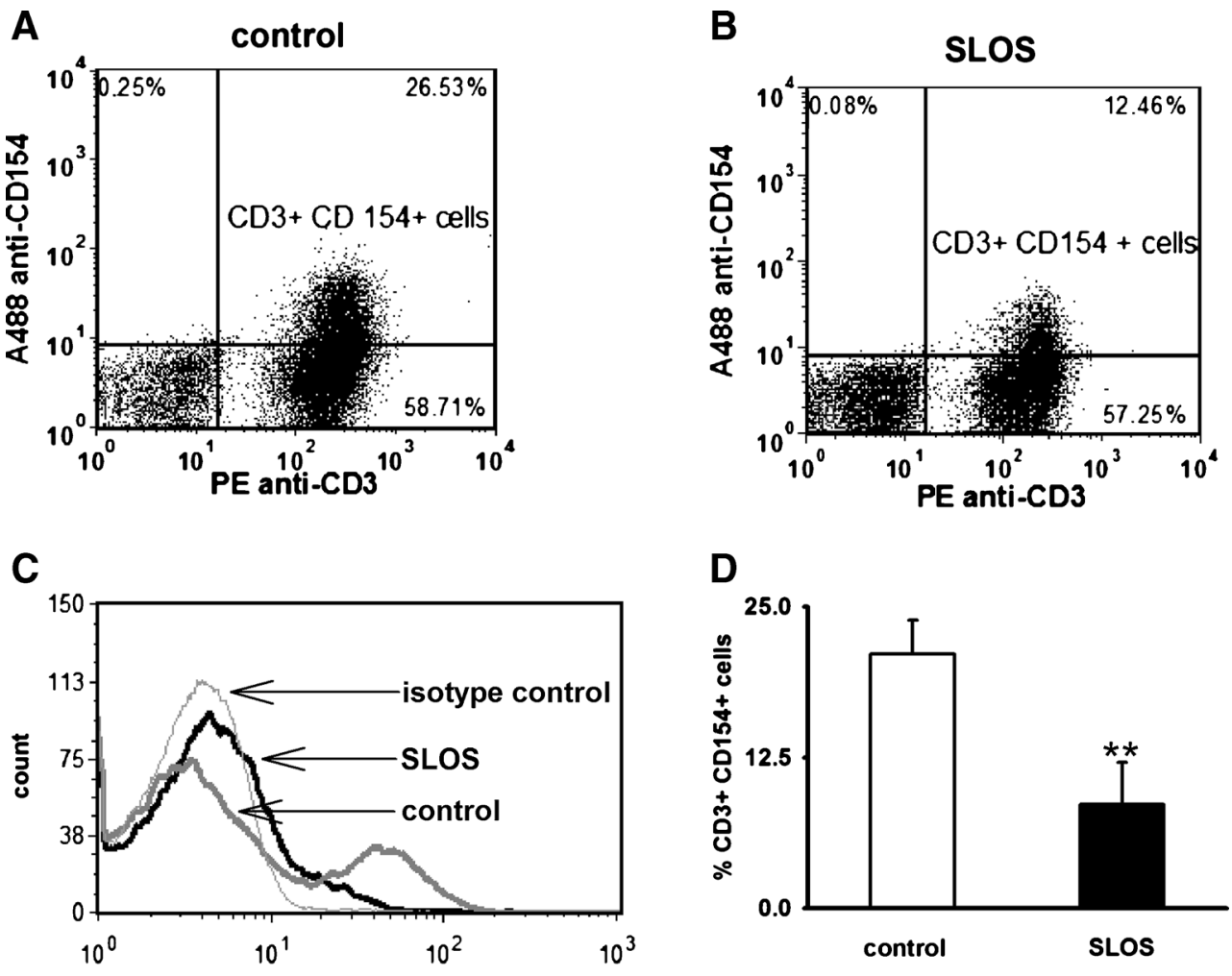

Fig. 6 CD154 expression in SLOS is hampered. a, $\mathbf{b}$ Representative dot-plots of flow cytometric measurement for healthy (control) (a) and SLOS (b) PBMCs labeled with anti CD3-PE and anti-CD154Alexa488 after a 3-h activation with thapsigargin $(1 \mu \mathrm{M})$. c CD154 expression distribution of $\mathrm{CD}^{+} \mathrm{T}$ cells of a healthy and an SLOS donor upon thapsigargin activation (isotype control is also shown). d Mean percentage of $\mathrm{CD} 154^{+} \mathrm{CD}^{+} \mathrm{T}$ cells in SLOS $(n=5)$ and healthy $(n=4)$ group (mean \pm SEM is displayed, *significant difference for $p=0.05$ ) 
Fig. 7 Proliferation of T cells in SLOS is impaired (a, b). Dotplots show the gating procedure for lymphocytes based on their light-scatter properties (SSC vs. FSC). a The stimulated control PBMC population on day 0 , and b the stimulated population on day 5 following activation: activated $\mathrm{T}$ cells have higher light scatter intensities and mainly dead cells are outside the gate. $\mathbf{c}, \mathbf{d}$ CFSE fluorescence intensity histograms obtained for a healthy donor (c) and a representative SLOS sample (d). A marker was placed over the divided $(D)$ and to the undivided cell (U.D.) subpopulations. e The ratio of divided cells and all gated cells is shown for SLOS $(n=4)$ and control $(n=4)$ group (data is represented as mean $\pm \mathrm{SEM}$, $* * p=0.007$ )
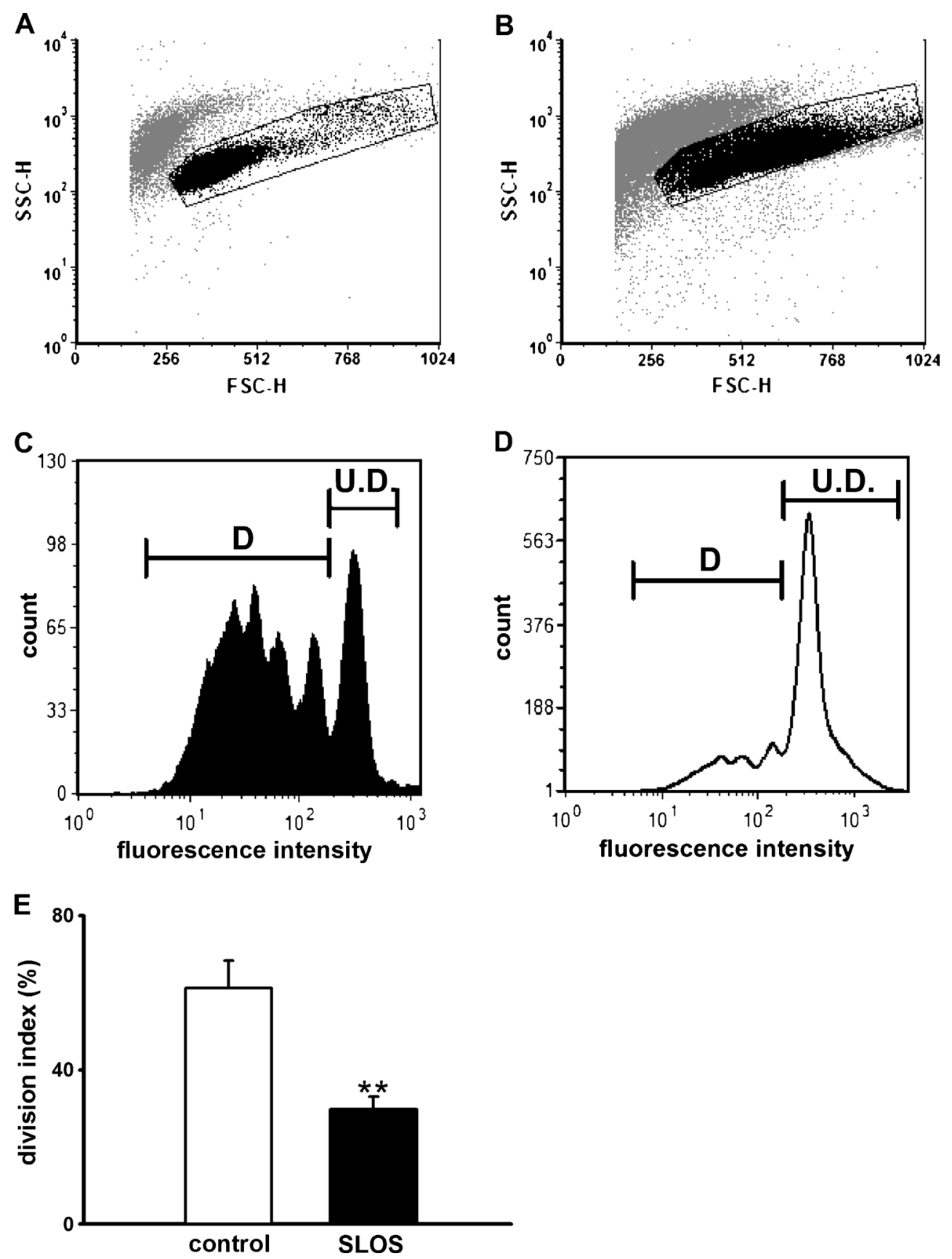

manipulation of the sterol level of $\mathrm{T}$ cell membranes with $\mathrm{M} \beta \mathrm{CD} / 7 \mathrm{DHC}$ complex clearly indicated an elevation of 7DHC level, while the CHOL content reduced mildly (Fig. 3a). We are aware that 7DHC enrichment of the T cell membrane using $\mathrm{M} \beta \mathrm{CD}$ and the consequent altered ratio of $7 \mathrm{DHC} / \mathrm{CHOL}$ only partly mimics the SLOS plasma membrane. For example, other species of CHOL precursors and 7DHC-derived oxysterols were not present in the T cells treated with $\mathrm{M} \beta \mathrm{CD}$ complexed to $\mathrm{CHOL}$ or $7 \mathrm{DHC}$ whereas these compounds are identified in SLOS cells [7, 8, 66, 67]. Nevertheless, 7DHC is the prominent sterol in the SLOS membrane and the biophysical parameters of Kv1.3 gating were similarly affected in SLOS and in T cells treated with $\mathrm{M} \beta \mathrm{CD} / 7 \mathrm{DHC}$ complex. This suggests that acute loading of $\mathrm{T}$ cells with 7DHC mimics adequately the effect of the lipid milieu existing in SLOS on the operation of Kv1.3 [11, 29, 30, 54, 68].

We showed clearly that the voltage dependence of steadystate activation of Kv1.3 is shifted to more depolarized potentials in SLOS T cells as compared to age-matched control T cells. However, the shift in the $V_{1 / 2}$ is relatively small in SLOS $\mathrm{T}$ cells as compared to $\mathrm{T}$ cells treated with $\mathrm{M} \beta \mathrm{CD} / 7 \mathrm{DHC}$. This could be explained by the heterogeneity of the patient group regarding $7 \mathrm{DHC}$ levels, $7 \mathrm{DHC} / \mathrm{CHOL}$ ratio or the 
severity of the disease. Nevertheless, the very clear and monotonic dose dependence of the activation time constant and the $V_{1 / 2}$ on the $\mathrm{M} \beta \mathrm{CD} / 7 \mathrm{DHC}$ concentration (Fig. 3) suggests that the gating parameters of $\mathrm{Kv} 1.3$ are qualitatively and quantitatively related to 7DHC loading of the cells. Here, we would also note that we could not identify a correlation between the 7DHC level (or 7DHC/CHOL ratio) and the extent of the change in Kv1.3 biophysical parameters in SLOS T cells. This latter may be explained by the low number of donors included in this study.

Our experiments also addressed an obvious question: how does the altered membrane sterol composition impair the gating of Kv1.3 in SLOS? According to the current theories sterols and ion channels can interact directly or membrane sterols can affect the operation of ion channels by influencing the biophysical properties of the cell membrane (membrane fluidity, membrane compartmentalization) [11, 20, 34]. Strong pieces of evidence support both theories and these two models are not mutually exclusive. The effect of 7DHC on the biophysical properties of the cell membrane is contradictory. For example, it has been demonstrated that 7DHC destabilizes cholesterol rich domains, increases the membrane fluidity and alters the protein pattern of rafts $[11,30,61]$. On the contrary, according to Liu et al., the difference between $\mathrm{CHOL}$ and $7 \mathrm{DHC}$ from the perspective of membrane ordering and condensation is essentially imperceptible [35]. All in all, we cannot exclude the possibility of the indirect regulatory effect of 7DHC on Kv1.3 gating.

On the other hand, $\mathrm{CHOL}$ is a prominent component of the annular lipid belt around the transmembrane segment of ion channels thereby stabilizing the conformation of the channel [33]. It seems that VSDs and not the pore domain of $\mathrm{KV}$ channels require the lipid belt [50]. Recent structure function studies show that the VSDs of Kv1.2 are positioned at the corners of the square-shaped PD creating deep grooves between the adjacent subunits. These grooves are expected to be filled with lipids whose ordering may be different than the rest of the membrane, generating optimal environment for specific lipid-protein interactions [60]. In SLOS, 7DHC substitutes CHOL in the cell membrane and may impair direct CHOL-protein interactions of annular lipids which may result in altered operation of the VSD's.

As for the specific CHOL-ion channel interaction, several CHOL binding motifs of the membrane and intracellular proteins have been described in the literature recently (CRAC, CARC, and CCM motif), which serve as specific CHOL receptor sites [20,34]. Due to the low stringency requirements for the amino acid pattern of these motifs should be accepted with careful skepticism but it is notable that a simple point mutation or deletion of these selected motifs could totally abolish CHOL sensitivity of ion channels [44, 49, 52]. Based on the work of Dopico et al., we identified several CARC and CRAC motifs randomly distributed along the amino acid sequence of Kv1.3 (including N-terminal, transmembrane segments and the C-terminus of the channel) [52]. Some of them overlapped with highly conservative residues of $\mathrm{Kv}$ channels such as the voltage sensor or the activation gate, others were located on the variable regions of the Kv1.3. Mutational analysis of the conservative regions would be problematic since it has been demonstrated that simple point mutations of identical parts of Shaker channel can cause nonconducting channels $[25,32]$. On the contrary, relatively large perturbations in the distal C-terminus of the channel are well tolerated without a significant effect on the gating of Kv1.3 [57]. Therefore, we decided to study a mutant Kv1.3 which lacks the putative cholesterol motifs of the distal $\mathrm{C}$-terminal. Surprisingly, truncation of the distal C-terminus resulted in a phenotype that was resistant to the manipulation of CHOL and 7DHC content of the membrane (Fig. 5). We propose that CARC motifs of the C-terminal interact with membrane cholesterol of the inner leaflet via their hydrophobic residues and mediate sterol sensitivity of Kv1.3. A similar conclusion was reached by Robinson et al. who envisioned that the $\mathrm{C}$-terminal of the P2X7 ion channel dips back into the plasma membrane and contacts the membrane via palmitoyl groups and hydrophobic residues [49]. Further experiments including mutagenic scanning analysis of the putative C-terminal cholesterol recognition sites are necessary to reveal the exact identity/ function of the CARC/CRAC domains of Kv1.3. It is also notable, that other members of the Kv family have distinct amino acid residues from Kv1.3 at equivalent positions, which do not fulfill the requirement of the CRAC or CARC pattern and thus, their sensitivity to sterols might be different. Furthermore, 7DHC, at identical loading concentrations, is more effective in changing the biophysical parameters of Kv1.3 gating than CHOL (Fig. 4). This may imply that the affinity of the sterol binding motif of Kv1.3 is different for CHOL and 7DHC and/or the bound sterols affect ion channel function differently (e.g., affecting the coupling between the VSD and the PD through the activation gate of the channel which is located close to the sterol binding domains).

SLOS $\mathrm{T}$ cells had the same current density as the agematched control whereas "acute" in vitro 7DHC elevation in the membrane decreased the current density, which can be accounted for by the suppression of the Kv1.3 current (Figs. 1c and 3f). We think this discrepancy can be explained with the "exposure time" to 7DHC treatment: under in vivo circumstances, the cells can build up compensatory mechanisms resulting in the same whole-cell potassium conductance as for the control, while in vitro elevation of 7DHC level with its 60-min duration is not sufficient, e.g., to recruit new Kv1.3 channels into the plasma membrane. We found a similar phenomenon in our former study, where acute cholesterol treatment decreased the current density of Kv1.3, whereas hypercholesterinaemic $\mathrm{T}$ cells had the same current density as the age-matched control [53]. Currently, we do not know 
either the nature of the reduction in the $\mathrm{K}^{+}$conductance upon acute exposure of the cells to sterols or the origin of the putative compensatory mechanism. The suppression of the current may originate from a change in any one or a combination of three possible factors due to increased $7 \mathrm{DHC} / \mathrm{CHOL}$ ratio: single channel current could decrease and/or open probability could decrease and/or number of channels could decrease $[13,15,52]$.

Several studies reported that the modification of the operation of ion channels due to inherited mutations, which is often hallmarked by the change in the equilibrium and kinetic parameters of activation (or inactivation), leads to diseases such as epilepsy (Kv1.2), episodic ataxia (Kv1.1), and long QT-syndrome (Kv7.1 or KCNQ1) [1, 2, 55]. We obtained similar changes in the biophysical parameters of Kv1.3 gating (slower activation kinetics and shift in the voltage dependence of steady-state activation toward positive potentials) in SLOS T cells as in channelopathies listed above. This rightward shift in the voltage dependence of steady-state activation can have pathophysiological consequences similar to the loss-offunction mutations. The more positive half-maximal voltage in SLOS T cells can lead to reduced activity of Kv1.3 channels under physiological conditions, which should appear in the cellular functions coupled to the activity of Kv1.3. Kv1.3 is a crucial voltage-gated ion channel of lymphocytes, and its main function is the membrane potential control of $\mathrm{T}$ cells, thereby providing constant driving force required for $\mathrm{Ca}^{2+}$ entry during $\mathrm{T}$ cell activation. Consequently, suppression of the function of Kv1.3 leads to impaired activation and proliferation [10]. Our data is consistent with this: upregulation of $\mathrm{CD} 154$ expression (an early, $\mathrm{Ca}^{2+}$-signal dependent marker of $\mathrm{T}$ cell activation) upon activation of SLOS $\mathrm{CD}^{+} \mathrm{T}$ lymphocytes showed a significant reduction as compared to healthy donors [6, 62]. Also, the "long-term effect" of modified operation of ion channels could be traced with the proliferation assay: SLOS cells tended to divide at a lower rate compared to control T cells, a phenomenon which was clearly shown for $\mathrm{Kv} 1.3$ inhibitors $[10,63]$. The $\mathrm{Ca}^{2+}$-signaling-linked activation of $\mathrm{T}$ lymphocytes is a classic example of the interplay of ion channels, transporters, and signaling molecules (see above), reviewed in [22, 64]. Even though the sterol sensitivity of Kv1.3 is a potential mechanism for the reduced $\mathrm{T}$ cell activation/proliferation, we cannot exclude that the altered lipid milieu in SLOS affects other transporters and/or signaling molecules, which contribute to the altered $\mathrm{T}$ cell function in SLOS. Also, we should not exclude the significance of the toxic effects of 7DHC and oxysterols (including 7DHCderived oxysterols), which were shown earlier to hinder activation and/or proliferation of cells and cause retinal degeneration in a rat model of SLOS $[21,40,68]$. It has been demonstrated that SLOS-derived fibroblasts show impaired $\mathrm{Na} / \mathrm{K}$ pump function, increased $\mathrm{Ca}^{2+}$ permeability, and reduced proliferation [61]. These data confirm our hypothesis that altered function of various ion transporters, such as the hereby studied

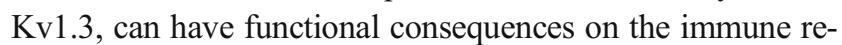
sponses in SLOS. In mouse models of SLOS (7DHR-/- animals), it was recently reported that mast cells showed constitutive cytokine production and hyper-degranulation upon IgE receptor activation, which occurred due to the altered raft system of SLOS cell membrane [31]. Even though immunodeficiency was not recognized initially as a part of SLOS, two recent case reports described serious infections in these patients. They proposed immunodeficiency behind this phenomenon, which is consistent with the data regarding altered $\mathrm{T}$ cell activation/proliferation $[3,9]$.

In summary, we showed that changes in the biophysical properties of Kv1.3 channels in SLOS are due to the altered 7DHC/CHOL ratio, and the sterol-channel interaction is conveyed by sterol binding motifs on the channel. Furthermore, the modified operation of Kv1.3 influences the linked cellular/ signaling processes, which can lead to the dysfunction of the cells. We also conclude that C-terminus of Kv1.3 is highly involved in the sterol-mediated regulation of the channel. Significance of the two putative CHOL binding sites not clear yet, but this experiment implies their role in the regulation of Kv1.3.

Acknowledgments This work was supported by Mecenatura (P.H.), TÁMOP-4.2.2.D-15/1/KONV-2015-0016 project (implemented through the New Széchenyi Plan co-financed by the European Social Fund, G.P.), GINOP 2.3.2-15 C122500 to GP, KTIA_NAP_13-2-2015-0009 (Z.V.), Hungarian Scientific Research Fund OTKA NN111006 (L.V.). P.H. is a Lajos Szodoray Fellow and supported by János Bolyai Fellowship. Z.V. is awarded with János Bolyai Fellowship. A.B was cofinanced by Astellas Pharma Fellowship and National Excellence Program. This research was partly realized in the frames of TÁMOP 4.2.4. A/2-11-1-2012-0001 "National Excellence Program - Elaborating and operating an inland student and researcher personal support system convergence program." The project was subsidized by the European Union and cofinanced by the European Social Fund.

\section{References}

1. Adelman JP, Bond CT, Pessia M, Maylie J (1995) Episodic ataxia results from voltage-dependent potassium channels with altered functions. Neuron 15:1449-1454

2. Arbour L, Rezazadeh S, Eldstrom J, Weget-Simms G, Rupps R, Dyer Z, Tibbits G, Accili E, Casey B, Kmetic A, Sanatani S, Fedida D (2008) A KCNQ1 V205M missense mutation causes a high rate of long QT syndrome in a First Nations community of northern British Columbia: a community-based approach to understanding the impact. Genet Med 10:545-550

3. Babovic-Vuksanovic D, Jacobson RM, Lindor NM, Weiler CR (2005) Selective antibody immune deficiency in a patient with Smith-Lemli-Opitz syndrome. J Inherit Metab Dis 28:181-186

4. Balogh G, Peter M, Liebisch G, Horvath I, Torok Z, Nagy E, Maslyanko A, Benko S, Schmitz G, Harwood JL, Vigh L (2010) Lipidomics reveals membrane lipid remodelling and release of potential lipid mediators during early stress responses in a murine melanoma cell line. Biochim Biophys Acta 1801:1036-1047 
5. Balogh I, Koczok K, Szabo GP, Torok O, Hadzsiev K, Csabi G, Balogh L, Dzsudzsak E, Ajzner E, Szabo L, Csakvary V, Olah AV (2012) Mutational spectrum of Smith-Lemli-Opitz syndrome patients in Hungary. Mol Syndromol 3:215-222

6. Banchereau J, Bazan F, Blanchard D, Briere F, Galizzi JP, van Kooten C, Liu YJ, Rousset F, Saeland S (1994) The CD40 antigen and its ligand. Annu Rev Immunol 12:881-922

7. Batta AK, Salen G, Tint GS, Shefer S (1995) Identification of 19nor-5,7,9(10)-cholestatrien-3 beta-ol in patients with Smith-LemliOpitz syndrome. J Lipid Res 36:2413-2418

8. Batta AK, Tint GS, Shefer S, Abuelo D, Salen G (1995) Identification of 8-dehydrocholesterol (cholesta-5,8-dien-3 betaol) in patients with Smith-Lemli-Opitz syndrome. J Lipid Res 36: 705-713

9. Beby-Defaux A, Maille L, Chabot S, Nassimi A, Oriot D, Agius G (2001) Fatal adenovirus type $7 \mathrm{~b}$ infection in a child with SmithLemli-Opitz syndrome. J Med Virol 65:66-69

10. Beeton C, Wulff H, Standifer NE, Azam P, Mullen KM, Pennington MW, Kolski-Andreaco A, Wei E, Grino A, Counts DR, Wang PH, LeeHealey CJ, B SA, Sankaranarayanan A, Homerick D, Roeck WW, Tehranzadeh J, Stanhope KL, Zimin P, Havel PJ, Griffey S, Knaus HG, Nepom GT, Gutman GA, Calabresi PA, Chandy KG (2006) Kv1.3 channels are a therapeutic target for T cell-mediated autoimmune diseases. Proc Natl Acad Sci U S A 103:17414-17419

11. Benesch MG, Lewis RN, McElhaney RN (2015) A calorimetric and spectroscopic comparison of the effects of cholesterol and its immediate biosynthetic precursors 7-dehydrocholesterol and desmosterol on the thermotropic phase behavior and organization of dipalmitoylphosphatidylcholine bilayer membranes. Chem Phys Lipids 191:123-135

12. Bianconi SE, Cross JL, Wassif CA, Porter FD (2015) Pathogenesis, epidemiology diagnosis and clinical aspects of Smith-Lemli-Opitz syndrome. Expert Opin Orphan Drugs 3:267-280

13. Borroni V, Baier CJ, Lang T, Bonini I, White MM, Garbus I, Barrantes FJ (2007) Cholesterol depletion activates rapid internalization of submicron-sized acetylcholine receptor domains at the cell membrane. Mol Membr Biol 24:1-15

14. Chandy KG, DeCoursey TE, Cahalan MD, McLaughlin C, Gupta S (1984) Voltage-gated potassium channels are required for human T lymphocyte activation. J Exp Med 160:369-385

15. Chang HM, Reitstetter R, Mason RP, Gruener R (1995) Attenuation of channel kinetics and conductance by cholesterol: an interpretation using structural stress as a unifying concept. J Membr Biol 143: $51-63$

16. Corso G, Gelzo M, Barone R, Clericuzio S, Pianese P, Nappi A, Dello RA (2011) Sterol profiles in plasma and erythrocyte membranes in patients with Smith-Lemli-Opitz syndrome: a six-year experience. Clin Chem Lab Med: CCLM/FESCC 49:2039-2046

17. Cross JL, Iben J, Simpson CL, Thurm A, Swedo S, Tierney E, Bailey-Wilson JE, Biesecker LG, Porter FD, Wassif CA (2015) Determination of the allelic frequency in Smith-Lemli-Opitz syndrome by analysis of massively parallel sequencing data sets. Clin Genet 87:570-575

18. DeCoursey TE, Chandy KG, Gupta S, Cahalan MD (1984) Voltage-gated $\mathrm{K}+$ channels in human $\mathrm{T}$ lymphocytes: a role in mitogenesis? Nature 307:465-468

19. Elias ER, Irons MB, Hurley AD, Tint GS, Salen G (1997) Clinical effects of cholesterol supplementation in six patients with the Smith-Lemli-Opitz syndrome (SLOS). Am J Med Genet 68: 305-310

20. Fantini J, Barrantes FJ (2013) How cholesterol interacts with membrane proteins: an exploration of cholesterol-binding sites including CRAC, CARC, and tilted domains. Front Physiol 4:31

21. Fernandez C, Martin M, Gomez-Coronado D, Lasuncion MA (2005) Effects of distal cholesterol biosynthesis inhibitors on cell proliferation and cell cycle progression. J Lipid Res 46:920-929
22. Feske S, Wulff H, Skolnik EY (2015) Ion channels in innate and adaptive immunity. Annu Rev Immunol 33:291-353

23. Gutman GA, Chandy KG, Grissmer S, Lazdunski M, McKinnon D, Pardo LA, Robertson GA, Rudy B, Sanguinetti MC, Stuhmer W, Wang X (2005) International Union of Pharmacology. LIII Nomenclature and molecular relationships of voltage-gated potassium channels. Pharmacol Rev 57:473-508

24. Haas D, Garbade SF, Vohwinkel C, Muschol N, Trefz FK, Penzien JM, Zschocke J, Hoffmann GF, Burgard P (2007) Effects of cholesterol and simvastatin treatment in patients with Smith-LemliOpitz syndrome (SLOS). J Inherit Metab Dis 30:375-387

25. Hackos DH, Chang TH, Swartz KJ (2002) Scanning the intracellular S6 activation gate in the shaker K+ channel. J Gen Physiol 119: 521-532

26. Hajdu P, Varga Z, Pieri C, Panyi G, and Jr Gaspar R. (2003) Cholesterol modifies the gating of Kv1.3 in human T lymphocytes. 445: 674-682.

27. Hajdu P, Varga Z, Pieri C, Panyi G, Gaspar R Jr (2003) Cholesterol modifies the gating of Kv1.3 in human T lymphocytes. Pflugers Arch - Eur J Physiol 445:674-682

28. Hamill OP, Marty A, Neher E, Sakmann B, Sigworth FJ (1981) Improved patch-clamp techniques for high-resolution current recording from cells and cell-free membrane patches. Pflugers Arch - Eur J Physiol 391:85-100

29. Irons M, Elias ER, Salen G, Tint GS, Batta AK (1993) Defective cholesterol biosynthesis in Smith-Lemli-Opitz syndrome. Lancet 341:1414

30. Keller RK, Arnold TP, Fliesler SJ (2004) Formation of 7 dehydrocholesterol-containing membrane rafts in vitro and in vivo, with relevance to the Smith-Lemli-Opitz syndrome. J Lipid Res 45:347-355

31. Kovarova M, Wassif CA, Odom S, Liao K, Porter FD, Rivera J (2006) Cholesterol deficiency in a mouse model of Smith-LemliOpitz syndrome reveals increased mast cell responsiveness. J Exp Med 203:1161-1171

32. Lee SY, Banerjee A, MacKinnon R (2009) Two separate interfaces between the voltage sensor and pore are required for the function of voltage-dependent $\mathrm{K}(+)$ channels. PLoS Biol 7:e47

33. Levitan I, Fang Y, Rosenhouse-Dantsker A, Romanenko V (2010) Cholesterol and ion channels. Sub-cellular Biochem 51:509-549

34. Levitan I, Singh DK, Rosenhouse-Dantsker A (2014) Cholesterol binding to ion channels. Front Physiol 5:65

35. Liu Y, Chipot C, Shao X, Cai W (2011) The effects of 7dehydrocholesterol on the structural properties of membranes. Phys Biol 8:056005

36. Lyons $\mathrm{AB}$ (2000) Analysing cell division in vivo and in vitro using flow cytometric measurement of CFSE dye dilution. J Immunol Methods 243:147-154

37. Lyons AB, Blake SJ, and Doherty KV (2013) Flow cytometric analysis of cell division by dilution of CFSE and related dyes. Current protocols in cytometry/editorial board, J Paul Robinson, managing editor [et al] Chapter 9: Unit9 11

38. Lyons AB, Parish CR (1994) Determination of lymphocyte division by flow cytometry. J Immunol Methods 171:131-137

39. Matteson DR, and Deutsch C. K channels in T lymphocytes: a patch clamp study using monoclonal antibody adhesion. 307: 468-471, 1984.

40. Moog C, Luu B, Altmeyer A, Bischoff P (1989) Studies on the immunosuppressive properties of 7,25 dihydroxycholesterol-II. Effects on early steps of T-cell activation. Int J Immunopharmacol 11:559-565

41. Nowaczyk MJ, Waye JS (2001) The Smith-Lemli-Opitz syndrome: a novel metabolic way of understanding developmental biology, embryogenesis, and dysmorphology. Clin Genet 59:375-386

42. Olah AV, Szabo GP, Varga J, Balogh L, Csabi G, Csakvary V, Erwa W, Balogh I (2013) Relation between biomarkers and clinical 
severity in patients with Smith-Lemli-Opitz syndrome. Eur J Pediatr 172:623-630

43. Petho Z, Balajthy A, Bartok A, Bene K, Somodi S, Szilagyi O, Rajnavolgyi E, Panyi G, Varga Z (2016) The anti-proliferative effect of cation channel blockers in $\mathrm{T}$ lymphocytes depends on the strength of mitogenic stimulation. Immunol Lett 171:60-69

44. Picazo-Juarez G, Romero-Suarez S, Nieto-Posadas A, Llorente I, Jara-Oseguera A, Briggs M, McIntosh TJ, Simon SA, Ladron-deGuevara E, Islas LD, Rosenbaum T (2011) Identification of a binding motif in the S5 helix that confers cholesterol sensitivity to the TRPV1 ion channel. J Biol Chem 286:24966-24976

45. Porter FD (2008) Smith-Lemli-Opitz syndrome: pathogenesis, diagnosis and management. Eur J Hum Genet: EJHG 16:535-541

46. Porter FD, Herman GE (2011) Malformation syndromes caused by disorders of cholesterol synthesis. J Lipid Res 52:6-34

47. Price M, Lee SC, Deutsch C (1989) Charybdotoxin inhibits proliferation and interleukin 2 production in human peripheral blood lymphocytes. Proc Natl Acad Sci U S A 86:10171-10175

48. Ren G, Jacob RF, Kaulin Y, Dimuzio P, Xie Y, Mason RP, Tint GS, Steiner RD, Roullet JB, Merkens L, Whitaker-Menezes D, Frank PG, Lisanti MP, Cox RH, Tulenko TN (2011) Alterations in membrane caveolae and BKCa channel activity in skin fibroblasts in Smith-Lemli-Opitz syndrome. Mol Genet Metab 104:346-355

49. Robinson LE, Shridar M, Smith P, Murrell-Lagnado RD (2014) Plasma membrane cholesterol as a regulator of human and rodent P2X7 receptor activation and sensitization. J Biol Chem 289: 31983-31994

50. Schmidt D, Jiang QX, MacKinnon R (2006) Phospholipids and the origin of cationic gating charges in voltage sensors. Nature 444: 775-779

51. Simons K, Ikonen E (2000) How cells handle cholesterol. Science 290:1721-1726

52. Singh AK, McMillan J, Bukiya AN, Burton B, Parrill AL, Dopico AM (2012) Multiple cholesterol recognition/interaction amino acid consensus (CRAC) motifs in cytosolic $\mathrm{C}$ tail of Slo1 subunit determine cholesterol sensitivity of $\mathrm{Ca} 2+-$ and voltage-gated $\mathrm{K}+(\mathrm{BK})$ channels. J Biol Chem 287:20509-20521

53. Somodi S, Balajthy A, Szilagyi O, Petho Z, Harangi M, Paragh G, Panyi G, Hajdu P (2013) Analysis of the K+ current in human CD4+ T lymphocytes in hypercholesterolemic state. Cell Immunol 281:20-26

54. Staneva G, Chachaty C, Wolf C, Quinn PJ (2010) Comparison of the liquid-ordered bilayer phases containing cholesterol or 7dehydrocholesterol in modeling Smith-Lemli-Opitz syndrome. J Lipid Res 51:1810-1822

55. Syrbe S, Hedrich UB, Riesch E, Djemie T, Muller S, Moller RS, Maher B, Hernandez-Hernandez L, Synofzik M, Caglayan HS, Arslan M, Serratosa JM, Nothnagel M, May P, Krause R, Loffler H, Detert K, Dorn T, Vogt H, Kramer G, Schols L, Mullis PE, Linnankivi T, Lehesjoki AE, Sterbova K, Craiu DC, Hoffman-
Zacharska D, Korff CM, Weber YG, Steinlin M, Gallati S, Bertsche A, Bernhard MK, Merkenschlager A, Kiess W, Gonzalez M, Zuchner S, Palotie A, Suls A, De Jonghe P, Helbig I, Biskup S, Wolff M, Maljevic S, Schule R, Sisodiya SM, Weckhuysen S, Lerche H, Lemke JR (2015) De novo loss- or gain-of-function mutations in KCNA2 cause epileptic encephalopathy. Nat Genet 47:393-399

56. Szabo GP, Olah AV, Kozak L, Balogh E, Nagy A, Blahakova I, Olah E (2010) A patient with Smith-Lemli-Opitz syndrome: novel mutation of the DHCR7 gene and effects of therapy with simvastatin and cholesterol supplement. Eur J Pediatr 169:121-123

57. Szilagyi O, Boratko A, Panyi G, Hajdu P (2013) The role of PSD95 in the rearrangement of Kv1.3 channels to the immunological synapse. Pflugers Arch - Eur J Physiol 465:1341-1353

58. Tierney E, Conley SK, Goodwin H, Porter FD (2010) Analysis of short-term behavioral effects of dietary cholesterol supplementation in Smith-Lemli-Opitz syndrome. Am J Med Genet A 152A:91-95

59. Tint GS, Irons M, Elias ER, Batta AK, Frieden R, Chen TS, Salen G (1994) Defective cholesterol biosynthesis associated with the Smith-Lemli-Opitz syndrome. N Engl J Med 330:107-113

60. Tombola F, Pathak MM, Isacoff EY (2006) How does voltage open an ion channel? Annu Rev Cell Dev Biol 22:23-52

61. Tulenko TN, Boeze-Battaglia K, Mason RP, Tint GS, Steiner RD, Connor WE, Labelle EF (2006) A membrane defect in the pathogenesis of the Smith-Lemli-Opitz syndrome. J Lipid Res 47: 134-143

62. van Kooten C, Banchereau J (2000) CD40-CD40 ligand. J Leukoc Biol 67:2-17

63. Varga Z, Gurrola-Briones G, Papp F, Rodriguez de la Vega RC, Pedraza-Alva G, Tajhya RB, Gaspar R, Cardenas L, Rosenstein Y, Beeton C, Possani LD, Panyi G (2012) Vm24, a natural immunosuppressive peptide, potently and selectively blocks Kv1.3 potassium channels of human T cells. Mol Pharmacol 82:372-382

64. Varga Z, Hajdu P, Panyi G (2010) Ion channels in T lymphocytes: an update on facts, mechanisms and therapeutic targeting in autoimmune diseases. Immunol Lett 130:19-25

65. Witsch-Baumgartner M, Lanthaler B (2015) Birthday of a syndrome: 50 years anniversary of Smith-Lemli-Opitz Syndrome. Eur J Hum Genet: EJHG 23:277-278

66. Xu L, Liu W, Sheflin LG, Fliesler SJ, Porter NA (2011) Novel oxysterols observed in tissues and fluids of AY9944-treated rats: a model for Smith-Lemli-Opitz syndrome. J Lipid Res 52:1810-1820

67. Xu L, Porter NA (2015) Free radical oxidation of cholesterol and its precursors: Implications in cholesterol biosynthesis disorders. Free Radic Res 49:835-849

68. Xu L, Sheflin LG, Porter NA, Fliesler SJ (2012) 7 Dehydrocholesterol-derived oxysterols and retinal degeneration in a rat model of Smith-Lemli-Opitz syndrome. Biochim Biophys Acta 1821:877-883 